
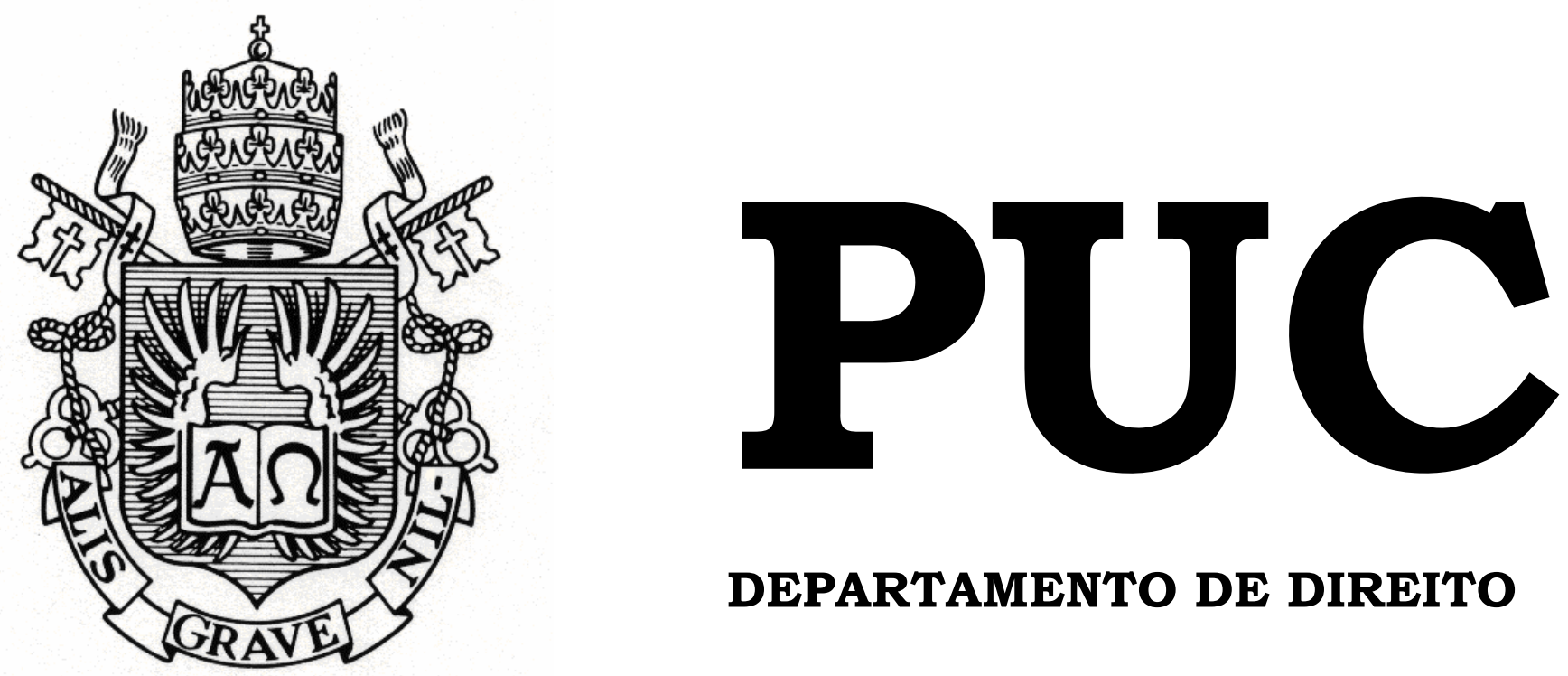

DEPARTAMENTO DE DIREITO

ASPECTOS POLÊMICOS DA LEI 11.101/05 E SUAS IMPLICAÇÕES NO PROCESSO DO TRABALHO: AS LIÇÕES DO CASO VARIG

por

ANA CAROLINA QUINTANILHA DOS SANTOS

ORIENTADOR: Lila Carolina Igrejas Lopes

2008.2

PONTIFÍCIA UNIVERSIDADE CATÓLICA DO RIO DE JANEIRO

RUA MARQUÊS DE SÃO VICENTE, 225 - CEP 22453-900

RIO DE JANEIRO - BRASIL 


\title{
ASPECTOS POLÊMICOS DA LEI 11.101/05 E SUAS IMPLICAÇÕES NO PROCESSO DO TRABALHO: AS LIÇÕES DO CASO VARIG
}

\author{
por
}

ANA CAROLINA QUINTANILHA DOS SANTOS

Monografia apresentada ao

Departamento de Direito da

Pontificia Universidade Católica do

Rio de Janeiro (PUC-Rio) como requisito parcial para a obtenção do Título de Bacharel em Direito.

Orientadora: Profa. Lila Carolina Igrejas Lopes 
Dedico este trabalho

Ao Prof. Adriano Pilatti, por ter sido o início, Ao Prof. João Baptista, por ter me apontado o futuro, E à Prof. ${ }^{a}$ Lila Lopes, por tê-lo sido. 


\section{AGRADECIMENTOS:}

Aos responsáveis pela minha formação, meus pais, Bartolomeu e Suze. Por todo empenho e esforço que fizeram para realizar meus sonhos, e principalmente pela paciência e compreensão com minhas escolhas e “cabeçadas”. A minha querida irmã, pelo apoio incondicional. A toda a família, tios, primos, primas, pelo estímulo e carinho. Amo vocês.

Para Fernando Schreiner, meu grande incentivador, conselheiro, confidente e como se não bastasse, além de tudo, o melhor namorado do mundo. Pela sua compreensão, por vezes privando-se do convívio comigo, ajudou-me a abrir meus caminhos pelo mundo. A você que com sua palavra, seu silêncio, seu gesto, ou simplesmente com o olhar foi capaz de me dar forças para seguir adiante.

No caminho, tiver sorte de encontrar Thaís e Olívia, mais que amigas e companheiras de república, conseguimos, em alguma medida, montar longe de casa, um "lar".

Aos companheiros de turma, com os quais tive o privilégio de conviver por cinco anos, Carla, Gonçalinho, Carol, Bernard, Dani, Vitor, Fabi, Thiago, Débora, Plínio, Fabio, Léo e Rodrigo. Pelas valiosas conversas, amigos com os quais aprendi as preciosas dimensões da alegria nos momentos que partilhamos. Enfim, pela parceria e lealdade, obrigada.

Com os amigos PET (Programa de Educação Tutorial), Julinha, Paula, Musa, Tainá, Tábata, Aline, Marcela, e na ala masculina, Bernardo, Leandro, Fred, Bruno, Chico, e também obviamente, com os membros da "velha guarda", em especial, Julia Alexim, Bernardo Bianchi, Jorge e Caetano, com os quais tive o privilégio de conviver e construir um espaço de reflexão, onde por pensarmos juntos, pensamos melhor, porque 
constituímos potência. Com vocês pude experimentar novos afetos, obrigada por terem lavado meus olhos e a minha alma com a realidade. Vocês me fizeram repensar o papel do Direito em nosso país.

Agradecimento especial ainda aos tutores do PET, aos Professores Adriano Pilatti e Francisco de Guimaraens. Gratidão eterna a vocês, mestres queridos, por tão generosamente partilharem conhecimento, por nos ajudar a compreender pela causa que Direito é produto e Política é a produção. Com vocês aprendemos que temos responsabilidades com nossas escolhas, e estas jamais são neutras ou triviais, representam uma forma de se posicionar no mundo. Continuarei sempre aprendiz, pois vocês nos ensinaram que devemos insistir, isto é, pensar.

Aos agradecimentos institucionais, por fim. Ao MEC e a Secretaria de Educação pelo financiamento do PET. Agradeço também à PUC Rio, muito especialmente Prof. Augusto Sampaio, não somente pela bolsa concedida, mas pela dedicação em seu trabalho, por tudo que representa para esta universidade. Aqui aprendi que realmente “com asas, nada é pesado”. Aos professores do curso de Direito, aos funcionários do departamento, especialmente Tião, Dudu, Bruno, Anderson, Leopoldo e Marcos, pela presteza e carinho no atendimento. Por resolverem nossos “pepinos”, pois sem o auxílio de vocês, tudo teria sido mais difícil. Aos demais funcionários, da xerox (Neto e Sandra), da Biblioteca (Beto), e dos que trabalham para manter nossas instalações limpas e em condições apropriadas para o estudo. Muito obrigada.

Aos que contribuíram valiosamente para elaboração deste trabalho concedendo entrevistas: Dr. Luiz Roberto Ayoub, Dr. Rodrigo Carelli, Sra. Marta Rezende Osório e Sr. Reynaldo Filho.

A Prof. ${ }^{a}$ Lila, não apenas pela orientação, mas pela disposição constante em dialogar, pelo nosso espaço de interlocução, pela abertura generosa de pensamento, muito obrigada! 


\section{RESUMO:}

O regime jurídico de insolvência representado pela Lei 11.101/05 (LRF) suscita muitas dúvidas que não são de simples solução. No novo diploma há clara ênfase à continuidade do negócio e esta mudança termina por repercutir na seara trabalhista, pois, em regra, os empregados estão sempre entre os credores das empresas em dificuldade. A proposta do presente estudo é fazer uma análise das conseqüências da LRF em relação ao trabalhador, tendo como substrato prático o emblemático exemplo do caso Varig. Preliminarmente discute-se a disputa de competência entre a vara empresarial e a trabalhista expressando a riqueza acadêmica do caso Varig. Em seguida é abordada a polêmica acerca da sucessão trabalhista na recuperação judicial e as diferenças entre o regramento do art. 60 § único versus art. 141 ambos das LRF. Por fim, restam as reflexões sobre a limitação dos créditos trabalhistas (art. 83, I LRF) e suas implicações no Direito Laboral. Destarte, a principal contribuição do presente estudo é o esforço de tentar compreender de maneira adequada as limitações e possibilidades de compatibilização dos institutos afetos ao Direito de Trabalho e do Direito Empresarial.

\section{PALAVRAS-CHAVE:}

Lei de recuperação judicial e falência, Varig, Competência, Sucessão trabalhista, Preservação da empresa, Princípio da continuidade da relação de emprego, Alienação de unidade produtiva, Créditos Trabalhistas, Quadro-Geral de Credores. 


\section{SUMÁRIO:}

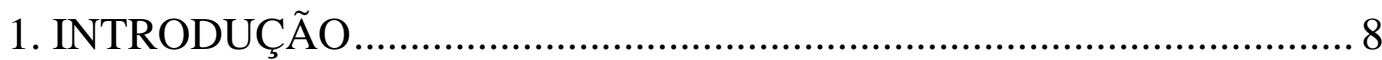

2. HISTÓRICO

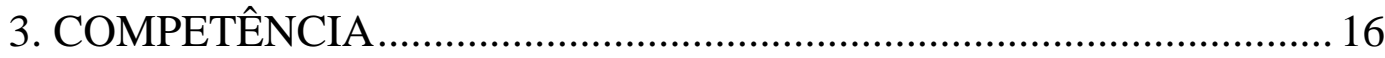

3.1 Questão do conflito de competência...................................................... 16

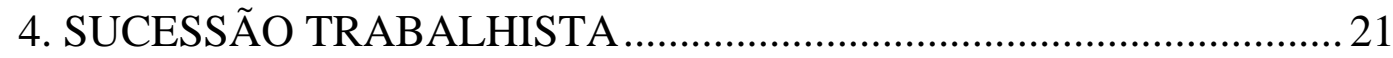

4.1. Sucessão de dívidas e o tratamento conferido pelo Código Civil de

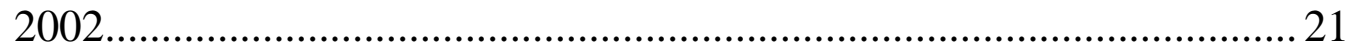

4.2. Das linhas gerais sobre o instituto da sucessão trabalhista................. 22

4.3. Sucessão Trabalhista e o princípio da continuidade do emprego e da

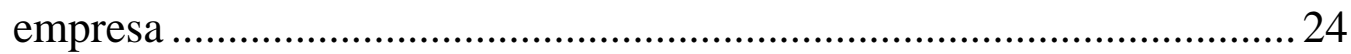

4.4. Polêmica entre o art. 60 § único versus art. 141, II (LRF) ................. 25

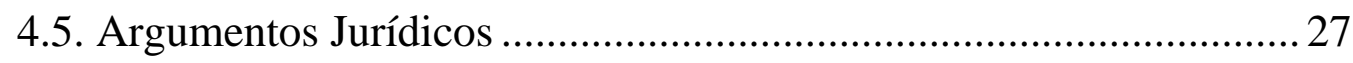

4.6. Argumentos Econômicos ...................................................................... 34

4.7. Argumentos Ideológicos ..................................................................... 40

5. LIMITAÇÃO DOS CRÉDITOS TRABALHISTAS .................................. 45

6. CONSIDERAÇÕES FINAIS ……………………........................... 54

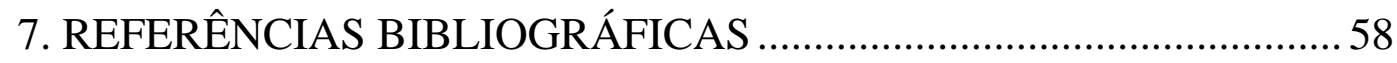

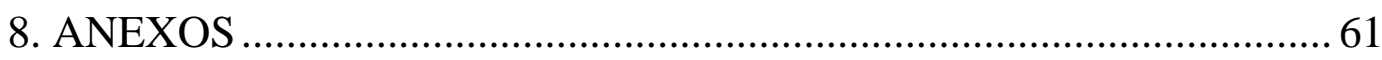

Anexo I: Entrevista com Dr. Luiz Roberto Ayoub...................................... 61

Anexo II: Entrevista com ex-comissária Marta Rezende Osório ...............67

Anexo III: Entrevista com Presidente da Associação dos Comissários .. 68 


\section{LISTA DE ABREVIAÇÕES:}

ANAC - Agência Nacional de Aviação Civil

CADE - Conselho Administrativo de Defesa Econômica do Consumidor

CC - conflito de competência

CCB - Código Civil Brasileiro

CLT - Consolidação das Leis de Trabalho

CRFB - Constituição da República Federativa do Brasil

LRF - Lei de Recuperação Judicial e Falência (Lei 11.101/05)

STF -Supremo Tribunal Federal

STJ - Superior Tribunal de Justiça

TRT - Tribunal Regional do Trabalho

TST - Tribunal Superior do Trabalho

UPV - Unidade Produtiva de Valor 


\section{INTRODUÇÃO:}

Em um país como o Brasil, onde ciclicamente são enfrentadas crises econômicas e instabilidades financeiras, comuns são os casos em que as atividades empresárias não logram êxito, acumulando dívidas que muitas vezes superam as forças do patrimônio da sociedade.

De modo singelo, a falência acaba por ser o reconhecimento jurídico da inviabilidade da empresa. É uma modalidade de execução coletiva na qual todos os bens do devedor falido são arrecadados visando pagamento de seus credores (empregados, fisco, bancos, fornecedores) de forma completa ou ao menos proporcional. A lógica é pagar o maior número possível de credores.

Resta patente que a edição da Lei 11.101, de 09 de fevereiro de 2005, após mais de uma década de tramitação no Congresso Nacional, trouxe significativas inovações à disciplina da recuperação judicial, extrajudicial e falência do empresário individual e da sociedade empresária. Na esteira do novo diploma há clara ênfase que privilegia não tanto a satisfação dos créditos devidos pelo empresário ou sociedade empresária, mas a própria continuidade no negócio.

Esta mudança de ênfase na finalidade da legislação termina por repercutir no campo trabalhista. A uma, porque a partir do momento em que os recursos financeiros da empresa escasseiam o pagamento de salários, indenizações trabalhistas e contribuições de natureza trabalhista ficam logo afetadas. A duas, porque os empregados estão sempre entre os credores das empresas em dificuldades.

CELSO MARCELO DE OLIVEIRA ${ }^{1}$ assevera que:

\footnotetext{
${ }^{1}$ OLIVEIRA, Celso Marcelo de, Comentários à nova lei de falência e recuperação de empresas, $1^{\text {a }}$ Edição, SP, Ed. IOB Thomson, 2005 (pg 85).
} 
"o objetivo econômico da recuperação judicial é permitir às empresas em dificuldades econômicas que se tornem participantes competitivas e produtivas da economia. Os beneficiados, sob este ponto de vista, serão não somente os entes econômicos diretamente envolvidos, como controladores, credores $e$ empregados, mas, principalmente, a sociedade”.

Consoante lição de MARCELO PAPALÉO DE SOUZA “um regime jurídico de insolvência representado pela lei 11.101/05 (LRF), suscita muitas dúvidas que não são de simples solução”. Tal legislação é complexa, envolve a interação de várias áreas do Direito, senão todas, implicando procedimentos e instrumentos para encaminhamento das soluções.

A análise das conseqüências da nova lei (LRF) em relação ao trabalhador é deveras importante, pois conduz o intérprete a tentativa de compatibilização dos institutos diversos, do Direito do Trabalho (com preocupação com os trabalhadores); do Direito Empresarial (preponderantemente preocupado com os credores e manutenção da empresa economicamente viável).

Neste ponto torna-se necessário justificar o porquê do "Caso Varig”. A riqueza acadêmica do caso, para além da ampla divulgação, é notória e pode, sem dúvida, ser considerado um leading case, um fantástico laboratório que gerou debates interessantíssimos. A trajetória do caso Varig parece ser um caso "bom para pensar" acerca da interdisciplinaridade do Direito, e as polêmicas acerca do novo regime jurídico de insolvência (LRF) e as relações trabalhistas.

Necessário para compreensão da crise, remontar as bases materiais históricas do surgimento e consolidação da Varig. Conforme trabalho de

\footnotetext{
${ }^{2}$ SOUZA, Marcelo Papaléo de, A inconstitucionalidade da restrição dos créditos trabalhistas na nova lei de falência art. 83, I, da lei 11.101/05, Revista LTr, São Paulo, vol. 71, nº2, p. 135-141, fevereiro de 2007.
} 
CRISTIANO FONSECA MONTEIRO ${ }^{3}$ a Varig construiu trajetória de pequena empresa à líder de mercado do seguinte modo:

“com a estratégia de constante articulação com o Poder Público. Ela teve sucesso num momento em que o Estado capitaneou o processo de desenvolvimento econômico do país, intensificando o controle sobre o transporte aéreo, entre as décadas de 1950 e 1970 Neste período, a Varig procurou construir uma imagem de "empresa a serviço do país", articulando-se especialmente ao modelo de desenvolvimento de "Brasil Grande" dos governos militares".

Contudo, essa simbologia não duraria para sempre. No início da década de noventa a Varig se vê desafiada por um novo modelo econômico baseado na redução do Estado e na ênfase no livre mercado. A entrada de novos atores no mercado da aviação comercial e um novo padrão de interação com o Poder Público com as empresas obrigou a imagem da "Varig Grande” a se repaginar, substituindo gradativamente a estratégia anterior por uma idéia de competitividade global, voltada para resultados financeiros.

O presente estudo tem por objetivo analisar os reflexos da LRF no Direito e no Processo do Trabalho tendo como pano de fundo o emblemático estudo prático do caso Varig.

Em sua trajetória primeiramente, analisa a questão da competência, que vem causando fecundo embate doutrinário, em virtude da disputa de competência entre as varas empresarial e trabalhista para declarar a existência ou não de sucessão.

Em seguida, cuida da polêmica discussão acerca o instituto da sucessão trabalhista principalmente, na hipótese de alienação de unidade produtiva em caso de recuperação judicial. No esforço de compreensão crítica do discurso dominante, qual seja, de não haver sucessão do passivo trabalhista na recuperação judicial, a análise argumentativa desdobra-se em três níveis: argumentos jurídicos, econômicos e ideológicos.

\footnotetext{
${ }^{3}$ MONTEIRO, Cristiano Fonseca,. A trajetória da Varig do Nacional-Desenvolvimentismo ao consenso Neoliberal. Rio de Janeiro. 2000. 120p. Dissertação (Mestrado em Sociologia) Departamento de Sociologia e Antropologia da Universidade Federal do Rio de Janeiro
} 
Posteriormente, no âmbito da falência, discute a controvertida regra do art. 83, I da LRF, a qual impõe o limite de 150 (cento e cinqüenta) salários-mínimos para o recebimento dos créditos trabalhistas na classificação dos créditos elencada no art. 83 caput do referido diploma.

Sob o prisma metodológico a abordagem escolhida foi o métodoindutivo. Ainda quanto a metodologia, adotou-se o plano de estudo nos moldes distributivos, qual seja, adequado aos trabalhos que consagram a dimensão de uma decisão judicial específica, analisando o objeto a partir de cada um dos ramos do Direito implicados na decisão, e a dicotomia de suas peculiares perspectivas. Observe-se, por oportuno, que o presente estudo não possui a pretensão de esgotar o tema, de ser tomado com uma fonte exaustiva. Visa tão somente dar conta do estado da arte na discussão das limitações e possibilidades na compatibilização dos institutos afetos aos Direito do Trabalho e do Direito Empresarial, sobretudo em pontos de interseção como os argüidos na LRF e refletidos neste trabalho. Busca, por fim, despertar a atenção à importância do tema na atual conjuntura sóciopolítica brasileira, tendo como paradigma o exemplo da Varig. 


\section{HISTÓRICO:}

Este capítulo do trabalho destina-se à análise das bases materiais e origens históricas do surgimento, consolidação e crise da Varig. Desde a primeira guerra mundial, a atividade aeronáutica havia se revelado um poderoso instrumento militar, alcançando um significado estratégico. A aviação passou a ser pólo de disputa entre nações que detinham tecnologia e buscavam expandir sua hegemonia pelo mundo.

\section{CRISTIANO FONSECA MONTEIRO ${ }^{4}$ relata que:}

"o surgimento da Varig está ligado a este jogo de poder, porque isso levou o governo alemão a prover tecnologia e mão-de-obra especializada num projeto de tentar fundar no Brasil uma empresa de transporte aéreo".

O alemão Otto Ernest Meyer, imigrante, veio para o Brasil e mobilizou apoio político e econômico no Sul tendo conseguido em 1925 que o governador do Rio Grande do Sul Borges de Medeiros levasse à Assembléia Legislativa levasse à votação uma proposta de concessão de isenção fiscal pelo prazo de 15 anos para o empreendimento. Ou seja, já no "ato fundador" podemos verificar a capacidade de articulação com o Poder Público que seria a mola propulsora de seu desenvolvimento. $\mathrm{O}$ fundador também angariou apoio dos proprietários do sul de origem germânica. Desta maneira, a Varig nasce em 07 de maio de 1927. No início, havia imensas dificuldades com os poucos recursos tecnológicos, tudo era realmente muito precário, não havia aeroporto, mas somente campos de pouso, os pilotos muitas vezes cumpriam o papel também de mecânicos. Por fim, pairava uma total inexistência de infra-estrutura de apoio ao vôo e a falta de um aparato institucional.

De acordo com o mesmo autor 5 :

\footnotetext{
${ }^{4}$ Id., A Varig e o Brasil entre o desenvolvimento nacional e a competitividade global. CivitasRevista de Ciências Sociais do Departamento da PUC-RS. Rio Grande do Sul, v. 7, n.1, p. 35-58, jan/jun. 2007.
} 


\footnotetext{
"Na Varig, o sentimento "anti-germânico”com a Segunda Guerra Mundial provoca a renúncia de Otto Meyer à presidência da empresa. (...) tendo sido substituído por Ruben Martin Berta. Ele fora o primeiro funcionário da Varig, $e$ sob sua liderança, a empresa se expande de forma surpreendente (...)”.
}

Durante o Governo Goulart, trazem à baila a proposta da criação de uma estatal do setor, que foi apelidada de Aerobrás, a qual não nasceu graças a um forte lobby da Varig, que desde sua criação já revelou-se hábil na negociação com os governos.

As décadas de 50 à 70 foram o auge da empresa. A esta altura a Varig já detinha rotas internacionais e uma série de outros serviços. Porém, desde o golpe de 64 o departamento de aviação civil já começava a sinalizar que as empresas não deveriam depender de subsídios governamentais, de modo que os usuários deveriam arcar com os custos da operação, o que implicava a concentração do serviço nas classes de maior poder aquisitivo. Este foi também o período da construção do simbolismo associado à empresa. A Varig cultivou a imagem de empresa "a serviço do país”, a transportadora “oficial” dos presidentes da República, de diversas outras autoridades, da seleção brasileira de futebol. Seus escritórios em cidades tais como New York, Paris, Hong Kong entre outros, eram procurados por turistas brasileiros em apuros neste países, como por exemplo com a perda de documentos, funcionando nestes núcleos quase como uma filial da embaixada brasileira.

Mas as condições políticas e econômicas que deram lastro a este modelo logo seriam questionadas. A virada para década de 80 foi marcada pelo fracasso do projeto "Brasil grande" e houve certo descompasso da estratégia da "Varig grande” para a agenda governamental da década de 90, que passa a se orientar por uma estratégia mais consistente com a agenda da globalização e da competitividade. A rigor, historicamente, este processo não passou do lado amargo de nosso falso “milagre econômico”.

\footnotetext{
${ }^{5}$ Id. Viação Aérea Rio-Grandense: Quem está acima de tudo?. In: KIRSCHNER, Ana Maria
} 


\title{
Como bem notado por CRISTIANO F. MONTEIRO ${ }^{6}$
}

\begin{abstract}
"Deve-se destacar que o perfil da empresas aéreas brasileiras, junto com as norte-americanas, é distinto daquele de outros países. Brasil e Estados Unidos são os únicos onde o setor de aviação sempre foi predominantemente privado, apesar da regulamentação estatal significativa, como se verá. A regulamentação foi abruptamente eliminada pelo governo de Ronald Reagen nos EUA, no início do anos 80, e no Brasil, foi Fernando Collor o responsável pela sua desregulamentação (...) Este processo só se deu, todavia, após longos anos de subsídios, intervenções, e manipulações das mais diversas para o benefício de algumas empresas, deixando claro o papel do Estado na consolidação ou derrocada de gigantes da aviação brasileira e norte-americana”.
\end{abstract}

Em 92 foi a primeira vez que a empresa teve de promover um expressivo corte de funcionários. Depois, isso virou constante, em 94 corte de 3.586 funcionários, em 95 foram 7.089 perdas de postos de trabalho. A primeira grande crise da aviação comercial desde o Plano Real foi em 99 com a desvalorização da moeda brasileira frente ao dólar, depois veio o atentado terrorista de 11 de setembro que prejudicou todo o setor.

Há mais de quinze anos a empresa apresenta balanços financeiros negativos, além de ter mudado de comando mais de cinco vezes nos últimos seis anos. Com dívidas estimadas em mais de sete bilhões de reais, as dificuldades enfrentadas pela empresa foram complementadas por uma administração muito ineficiente.

Em 2003, o governo tentou promover uma fusão entre a Varig e a TAM, parte de um projeto para reduzir os custos operacionais de um setor que ainda sofria as conseqüências dos ataques terroristas de 11 de setembro de 2001, mas que não resultou exitosa. A Varig foi a primeira grande empresa do país a se beneficiar do processo de recuperação judicial, tendo em vista que a nova lei de falências foi aprovada no dia 9 de junho de 2005. Em 22 de junho de 2005 a justiça brasileira deferiu o pedido de recuperação judicial protocolado em 17 de junho do mesmo ano pela Varig.

(Org.). Brasil: Mosaico dos anos 90, RJ: IFCS/UFRJ, p. 73-101, 1999.

${ }^{6}$ Id. A dinâmica política das reformas para o mercado na aviação comercial brasileira (19902002). Rio de Janeiro, Agosto 2004. 252 p. Tese (Doutorado em Sociologia e Antropologia) IFCS/UFRJ. 
De acordo com informações veiculadas pelo jornal eletrônico ÚLTIMO SEGUNDO ${ }^{7}$ :

"em 20 de julho de 2006, a empresa foi vendida por US\$ 24 milhões de dólares ( $R \$$ 52,3 milhões no cambio da época), em leilão, para a VarigLog Menos de um ano após ter sido vendida em leilão, a Nova Varig (ou a parte saudável da Varig) mudou de mãos e em 09 de abril de 2007 foi vendida para a Gol Transportes Aéreos numa operação de U\$ 320 milhões de dólares. Esta venda foi aprovada pela ANAC (Agência de Aviação Civil) e pelo CADE (Conselho Administrativo de Defesa do Consumidor)".

Vale destacar que a VarigLog foi a única empresa a participar do leilão na época. No dia 28 de julho de 2006, já tendo sido deferido seu pedido de recuperação, a Varig demitiu 5000 (cinco mil) funcionários.

Acerca dos valores veiculados pela mídia (enorme diferença de preço de compra e de venda) cumpre lembrar as considerações feitas pelo juiz Dr. Luiz Roberto Ayoub $^{8}$ que de modo bem elucidativo esclarece e desmascara a falácia midiática destes números. Essencialmente, o valor divulgado do preço de venda de 24 milhões de dólares é falso, uma vez que desconsidera que preço é um conjunto de fatores com um ajuste complexo. Basicamente, foram desconsideradas aproximadamente 100 milhões em debêntures, os valores relativos à assunção de contratos de transporte a executar mais os valores do programa Smile. O real preço de venda foi de 277 milhões de dólares e que ao tempo da venda para a Gol seus ativos haviam valorizado principalmente em função do menor risco de aplicação da sucessão trabalhista, pois o STJ já havia pacificado a questão do conflito de competência.

\footnotetext{
${ }^{7}$ Jornal Último Segundo. Disponível em < http://ultimosegundo.ig.com.br/economia/2007/03/28/> Acesso.em 14 jun, 2008.

${ }^{8}$ Anexo 1 - Entrevista concedida na fase de elaboração deste trabalho em 22/10/2008. Em linhas gerais, vale ressaltar alguns trechos "Os números divulgados na imprensa são falsos (...) No dia do leilão a Varig só tinha 2 aviões.O preço é uma composição de fatores. É um ajuste complexo. $O$ valor de 24 milhões não incluía uma série de valores tais como as debêntures no total de 100 milhões, mais a assunção de contratos de transporte a executar mais a assunção do programa Smile. Salvo engano ela foi adquirida por algo em torno de 277 milhões de dólares (...)E havia um risco enorme de sucessão naquele momento, o risco é um fator de preço(...) A Gol pagou muito mais porque já eram 19 aviões, com recursos já investidos, já tinha uma musculatura maior, e terceiro já não havia tanto risco de sucessão porque o STJ já havia definido que a competência era minha (...)A situação fática no momento da venda era completamente outra".
} 


\section{COMPETÊNCIA:}

\section{1 - Questão do conflito de competência:}

Competência, de modo bem simplificado é a forma com se dá a atribuição de poder para decidir. Consoante o clássico conceito de LIEBMAN $^{9}$ competência "é a quantidade de jurisdição cujo exercício é atribuído a cada órgão ou grupo de órgãos”. Desta forma, competência pode ser expressa como a medida de jurisdição (cada órgão só exerce jurisdição dentro da medida que lhe fixam as regras sobre competência). ALEXANDRE CÂMARA ${ }^{10}$ preleciona complementarmente que "a questão não é de quantidade de jurisdição, mas dos limites em que cada órgão jurisdicional pode legitimamente exercer essa função estatal”.

Este tema passa a ser mais um ponto que revela a riqueza e complexidade do caso Varig, pois há disputa de competência entre a vara empresarial e a vara trabalhista, formando-se duas orientações a respeito, ambas com bons argumentos.

Na seara trabalhista a fundamentação gira em torno da competência constitucional. Com o advento da Emenda Constitucional n 45, o art. 114 da CRFB/88, que disciplina o regramento da jurisdição trabalhista passou a dispor nos seguintes termos:

\footnotetext{
Art. 114. Compete à Justiça do Trabalho processar e julgar: (Artigo alterado pela Emenda Constitucional $n^{\circ} 45$, de 08/12/2004) I - as ações oriundas da relação de trabalho, abrangidos os entes de direito público externo e da administração pública direta e indireta da União, dos Estados, do Distrito Federal e dos Municípios II - as ações que envolvam exercício do direito de greve;
}

\footnotetext{
${ }^{9}$ LIEBMAN Apud GRINOVER, Ada Pellegrini, Teoria Geral do Processo, $22^{\mathrm{a}}$ edição, SP, Ed. Malheiros, 2006 (pg. 246)

${ }^{10}$ CÂMARA, Alexandre Freitas, Lições de Direito Processual Civil, Volume I, 16 a edição, RJ Ed. Lumen Juris, 2007 (pg. 100)
} 
III - as ações sobre representação sindical, entre sindicatos, entre sindicatos e trabalhadores, e entre sindicatos e empregadores;

$I V$ - os mandados de segurança, habeas corpus e habeas data, quando o ato questionado envolver matéria sujeita à sua jurisdição;

$V$ - os conflitos de competência entre órgãos com jurisdição trabalhista, ressalvado o disposto no art. 102, I, o;

$V I$ - as ações de indenização por dano moral ou patrimonial, decorrentes da relação de trabalho;

VII - as ações relativas às penalidades administrativas impostas aos empregadores pelos órgãos de fiscalização das relações de trabalho;

VIII - a execução, de ofício, das contribuições sociais previstas no art. 195, I, a, e II, e seus acréscimos legais, decorrentes das sentenças que proferir;

IX - outras controvérsias decorrentes da relação de trabalho, na forma da lei

$\S 1^{\circ}$ - Frustrada a negociação coletiva, as partes poderão eleger árbitros.

$\S 2^{\circ}$ - Recusando-se qualquer das partes à negociação coletiva ou à arbitragem, é facultado às mesmas, de comum acordo, ajuizar dissídio coletivo de natureza econômica, podendo a Justiça do Trabalho decidir o conflito, respeitadas as disposições mínimas legais de proteção ao trabalho, bem como as convencionadas anteriormente.

$\S 3^{\circ}$ Em caso de greve em atividade essencial, com possibilidade de lesão do interesse público, o Ministério Público do Trabalho poderá ajuizar dissídio coletivo, competindo à Justiça do Trabalho decidir o conflito.

Entendemos, pois, que o art. 114 de CRFB/88 é cristalinamente claro, ao conferir à vara trabalhista a competência para apreciação acerca de existência ou não de sucessão de empregadores. Em abono a esta tese, a própria CLT é rica em dispositivos que tratam do tema. Em verdade a LRF cuida somente da mudança de ênfase na sucessão em caso de recuperação judicial, sem jamais ser capaz de per si, de afastar a competência constitucional da Justiça Laboral.

Neste sentido a própria LRF prevê em seu art. $6^{\circ} \S 2^{\circ}$ que as ações de natureza trabalhista serão processadas perante a Justiça especializada.

Art. $6^{\circ} \S 2^{\circ} \mathrm{LRF}$ : É permitido pleitear, perante o administrador judicial, habilitação, exclusão ou modificação de créditos derivados da relação de trabalho, mas as ações de natureza trabalhista, inclusive as impugnações a que se refere o art. 8 desta Lei, serão processadas perante a justiça especializada até a apuração do respectivo crédito, que será inscrito no quadro geral de credores pelo valor determinado em sentença. (grifos nossos). 
Acerca da temática vale o registro de como a questão vem sendo tratada de forma amplamente majoritária ${ }^{11}$ pela jurisprudência trabalhista:

\begin{abstract}
“(...) Ademais, apenas a Justiça do Trabalho tem competência para apreciar e julgar pedido de ocorrência de sucessão trabalhista e verbas daí decorrentes (art. 114 da CRFB. E não se diga que no caso das recuperações judiciais, a competência seria deslocada para a Justiça Comum uma vez que a Lei 11.101/05 também trata da sucessão, pois o que vai nortear a competência é o pedido que o Autor formula e não o provimento jurisdicional em tese. Desta forma, rejeito a preliminar de incompetência”.(grifos nossos).
\end{abstract}

$60^{\text {a }}$ VT/RJ, RT 01264.2006.060.01.00-2, sentença, Juíza do Trabalho Lila Carolina Igrejas Lopes, Rio de Janeiro, 14 jun, 2006.

“(...) A competência material da Justiça do Trabalho vem fixada art. 114 da Constituição federal, com a redação da Emenda Constitucional $n^{\circ}$ 45/2004. Compete à Justiça do Trabalho, assim, dirimir todas as questões oriundas das relações de trabalho, em sentido amplo. (...) Nada obstante, o art. $6^{\circ} \& 2^{\circ}$ da Lei $n^{\circ} 11.101 / 2005$ é preciso em determinar que as ações de natureza trabalhista serão processadas perante a justiça especializada até a apuração do respectivo crédito, o que afasta por completo a competência do Juízo da Vara Empresarial para analisar a presente demanda. (...) A competência material da Justiça do Trabalho abrange por inteiro a apreciação dos pedidos listados na peça de ingresso. Afasto a argüição das reclamadas".(grifos nossos).

$28^{\mathrm{a}}$ VT/RJ, RT 01022.2007.028.01.00-1, sentença, Juiz do Trabalho Paulo Rogério dos Santos, Rio de Janeiro, 27 nov, 2007.

"A Justiça do Trabalho é competente para conhecer, conciliar e julgar as lides decorrentes da relação de emprego, como as lesões às parcelas trabalhistas, $e$ também outras, ainda que morais, desde que decorrentes da relação de emprego, face o disposto no art. 114 da CRFB, à luz da teoria do sistema integrado de direitos, pelo que afasto a preliminar.

Ora, se a Constituição Federal apontou apenas para esta Especializada a competência para conhecer de verbas trabalhistas, não se pode conceber que tal competência seja deslocada para a Justiça Comum, pelo simples fato de tratar-se a matéria de recuperação judicial. Não.

A competência jurisdicional não pode se confundir com os efeitos decorrentes da recuperação judicial. Deste modo, em que pese ser desta Especializada a competência para a apreciação das lides trabalhistas, certo que é da Vara de Falência a competência para todos os assuntos decorrentes da recuperação judicial, competências estas muitos diferenciadas, motivo pelo qual certo que o Juízo da Falência não é competente para dizer acerca de parcelas controvertidas, bem como não é o trabalhista competente para executar bens da empresa em recuperação judicial.

Feitas estas distinções, deve ser ressaltado que a Justiça do Trabalho deve aplicar no caso concreto toda a legislação, ante o disposto no art. $8^{\circ}$ da CLT. Destarte, se necessário for, certo que o Juiz Trabalhista aplicará as normas insertas na nova lei de falências, o que não afasta a sua competência.

Assim, vislumbrar que o disposto na lei de falências afaste desta Especializada a sua competência natural importa em macular não só a necessária hierarquia das leis, bem como todos os princípios hermenêuticos utilizados para a interpretação

11 Existe orientação fortemente minoritária no sentido do acolhimento da preliminar de incompetência da Justiça Trabalhista para apreciar a demanda. 
das normas legais. Ora, o art. 114 da CRFB é expresso quanto a competência desta Justiça para apreciar as lides decorrentes da relação empregatícia, motivo pelo qual nunca foi novidade aqui a apreciação de existência ou não de sucessão de empregadores, matéria, aliás tratada com bastante vigor pela CLT. O que altera apenas a lei de falências é o enfoque da sucessão trabalhista quando da recuperação judicial, não se podendo admitir seja esta lei forte o suficiente para promover o afastamento da aplicação do texto constitucional quanto a competência Deste modo, afasto a preliminar"(grifos nossos).

$19^{\mathrm{a}}$ VT/RJ, RT 1725-2006-019-01-00-8, sentença, Juíza Substituta:

Fernanda Stipp, Rio de Janeiro, 06 out, 2007.

Em contrapartida a doutrina empresarial em peso sustenta que a LRF acabou por afastar da Justiça Trabalhista a competência na apreciação de sucessão trabalhista quando da recuperação judicial, uma vez que poderia colocar em risco o próprio instituto da recuperação. A principal linha argumentativa da seara empresarial $^{12}$ consiste no fato de sendo o juiz da recuperação o responsável por presidir o leilão, deve ser capaz de dizer sobre a sucessão, pois isto seria componente indispensável do preço.

Desta maneira, acerca da disputa de competência, refletindo o objetivo deste trabalho, qual seja, dar conta do estado da arte em que se encontram os debates da LRF com relação às implicações no processo do trabalho, temos que a questão já foi decidida unanimemente no $\mathrm{STJ}^{13}$, entendendo ser a vara empresarial a vitoriosa no conflito.

Do conflito de competência 61272, já pacificado no STJ originou-se o Recurso Extraordinário 583955/RJ, ainda não apreciado pelo STF, cujo relator é o Ministro Ricardo Lewandowski. Levando-se em consideração a extensa pauta do Supremo, provavelmente tal decisão não será firmada até o momento da apresentação oral do presente estudo monográfico. Cumpre destacar que, até o presente momento, houve apenas a manifestação da

\footnotetext{
${ }^{12}$ Anexo 1 - Entrevista concedida na fase de elaboração deste trabalho em 22/10/2008. Destaque para: "Quem é que preside o leilão: Sou eu, o juiz que está com a recuperação, tenho que dizer se há ou não sucessão porque isso é componente do preço. Você vai levar uma coisa sem saber se há ou não sucessão, qual é o preço? (...) Olha a insegurança jurídica. Então a manifestação sobre a sucessão trabalhista tem que ser prévia. Por isso que eu sempre defendi que a competência é da vara empresarial e não da justiça do trabalho. E foi assim é que o STJ julgou”.

${ }^{13}$ Conflito de competência n 61272.
} 
Procuradoria Geral da República ${ }^{14}$ pelo desprovimento do recurso, ou seja, pelo acerto da decisão do STJ conferindo à vara empresarial a competência para decidir sobre a sucessão trabalhista. Destaque-se o seguinte trecho do referido parecer:

"Ademais, conquanto a CLT trate, de forma genérica, da sucessão trabalhista, o art. 60, da Lei 11.101/05, referindo-se a empresas em recuperação judicial, estabelece, indistintamente, que a arrematação não acarretará transferência das obrigações do devedor ao arrematante. Sendo específica a disciplina, prevalece sobre a geral e atrai a competência da Justiça Comum - porquanto responsável pela elaboração e implementação do plano de recuperação judicial da empresa sede em que assinala as condições de aquisição.

Atribuir à Justiça Laboral a definição da responsabilidade do arrematante, vinculado às exigências estabelecidas no referido plano, poderia inutilizar os esforços empreendidos no sentido de evitar a quebra da sociedade empresária, sendo o Juízo perante o qual tramita o processo de recuperação judicial o mais indicado para decidir sobre a conveniência e a viabilidade da transmissão de obrigações, pois qualquer interferência nessa esfera deflagraria dificuldades gerenciais irremediáveis - em total oposição à essência e ao propósito da nova lei. (...)

Assim, agiu com acerto o Superior Tribunal de Justiça ao reconhecer a competência do Juízo da $1^{a}$ Vara Empresarial do Rio de Janeiro e a prevalência de sua determinação sobre a do Juízo Laboral, em face da nítida incompatibilidade prática das decisões" (grifos nossos).

Mais uma vez vale lembrar as dificuldades deste trabalho, tendo em vista que o cenário começa a ser construído gradualmente, a partir de uma legislação nova, estando por isso sujeito a incompletudes e certas imperfeições advindas da ausência de uma jurisprudência consolidada dos tribunais superiores que, oportunamente, se manifestarão orientando o caminho a ser trilhado por todos os atores envolvidos em conflitos desta natureza. Exatamente neste sentido que ressalvamos as dificuldades no trato da questão nova e extremamente complexa, mas de inquestionável interesse para o desenvolvimento do país.

\footnotetext{
${ }^{14}$ Parecer do Subprocurador-Geral da República Wagner de Castro Mathias Netto, de 19 de agosto de 2008.
} 


\section{SUCESSÃO TRABALHISTA NA LRF:}

\section{1 - Sucessão de dívidas e o tratamento conferido pelo Código Civil de 2002:}

Reza o art. 997 do novo Código Civil Brasileiro (CCB) que as sociedades personificadas simples se constituem mediante contrato escrito, particular ou público, prevendo de forma expressa que a Sociedade adquire direitos e assume obrigações.

De outro giro, preconiza o art. 1025 CCB que o sócio admitido em sociedade já constituída, não se exime das dívidas anteriores, ou seja, as dívidas de natureza trabalhista deverão ser suportadas pelo novo sócio em uma empresa, sopesando o art. 1025 CCB c/c arts. 10 e 448 CLT.

Art. 1025 CCB: O sócio admitido em sociedade já constituída, não se exime das dívidas sociais anteriores a admissão.

Ainda na esfera civilista, o Código Civil considera empresário aquele que exerce profissionalmente atividade econômica organizada para a produção ou a circulação de bens ou de serviços (art. 966), ao passo que disciplina o estabelecimento como todo o complexo de bens organizado, para o exercício da empresa, por empresário individual ou sociedade empresária e, caso haja alienação de seu objeto e se ao alienante não restarem bens suficientes para quitar o seu passivo, a eficácia da alienação do estabelecimento depende do pagamento de todos os credores, ou da anuência destes arts. 1142 c/c 1145.

Art. 1142: Considera-se estabelecimento todo o complexo de bens organizado, para exercício da empresa, por empresário, ou por sociedade empresária.

Art. 1145: Se ao alienante não restarem bens suficientes para solver o seu passivo, a eficácia da alienação do estabelecimento depende do pagamento de todos os credores, ou do consentimento destes, de modo expresso ou tácito, em 30 (trinta) dias a partir de sua notificação. 
Acerca da figura da responsabilidade do sucessor adquirente do estabelecimento, o Código Civil 2002 não deixa qualquer dúvida, vejamos:

Art. 1146: $O$ adquirente do estabelecimento responde pelo pagamento dos débitos anteriores a tranferência, desde que regularmente contabilizados, continuando o devedor primitivo solidariamente obrigado pelo prazo de 1 (um) ano, a partir, quanto aos créditos vencidos, da publicação, e, quanto aos outros, da data do vencimento. (grifos nossos).

Como resta meridianamente claro, o CCB 2002, em seu conteúdo privilegiou a função social do contrato (art. 421: A liberdade de contratar será exercida na razão e limites da função social do contrato), prevendo de forma cristalina que ao se inserir em uma sociedade, o novo sócio não se exime das dívidas sociais passadas (dentre elas, obviamente incluídas as de natureza trabalhista), ao mesmo tempo, previu que o adquirente do estabelecimento responderá pelo pagamento dos débitos anteriores a transferência (sem exclusão dos débitos trabalhistas) em perfeita consonância com os preceitos normativos e princípios que regem o Direito do Trabalho.

\section{2 - Das linhas gerais sobre o instituto da sucessão trabalhista:}

Consoante MAURÍCIO GODINHO DELGADO ${ }^{15}$, a sucessão de empregadores consiste "no instituto trabalhista em virtude do qual se opera, no contexto da transferência de titularidade de empresa ou estabelecimento, uma completa transmissão de créditos e assunção de dívidas trabalhistas entre alienante e adquirente envolvidos".

A figura é regulada nos seguintes termos:

Art. 10 CLT: Qualquer alteração na estrutura jurídica da empresa não afetará os direitos adquiridos por seus empregados.

\footnotetext{
${ }^{15}$ DELGADO, Maurício Godinho, Curso de Direito do Trabalho, Ed: Ltr, 5º edição, SP, 2006 (pag 406)
} 
Art. 448 CLT: A mudança na propriedade ou na estrutura jurídica da empresa não afetará os contratos de trabalho dos respectivos empregados.

O referido autor divide as situações-tipo para sucessão em dois gêneros, quais sejam, as tradicionais e as novas sucessões. As que se inserem dentro dos tipos clássicos são as que abrangem as modificações na modalidade societária ou derivam de processos de fusão, incorporação, cisão e outros correlatos. Também incluem a substituição do antigo titular passivo da relação empregatícia por outra pessoa física ou jurídica, nos casos de aquisição de estabelecimentos isolados.

Ocorre porém que, a generalidade e imprecisão dos artigos 10 e 448 da CLT têm permitido a jurisprudência proceder a uma adequação do tipo legal sucessório a situações fático-jurídicas novas surgidas no mercado empresarial dos últimos anos no país. No diapasão da sentença proferida pelo juiz MÚCIO NASCIMENTOS BORGES:

"essas situações novas, que se tornaram comuns no final do séc. $X X$, em decorrência da profunda reestruturação do mercado empresarial brasileiro (em especial o mercado financeiro, de privatizações e outros segmentos), conduziram a jurisprudência a reler os dois preceitos celetistas, encontrado neles um tipo legal mais amplo do que o originalmente concebido pela doutrina $e$ jurisprudência dominantes $" 16$.

Para essa nova interpretação, o sentido e objetivo do instituto sucessório trabalhista residem na garantia de que qualquer mudança INTRA ou INTEREMPRESARIAL não poderá afetar os contratos de trabalho.

"A luz desta vertente interpretativa, também configura situação própria a sucessão de empregadores a alienação ou transferência de parte significativa do(s) estabelecimento(s) ou da empresa de modo a afetar significativamente os contratos de trabalho ${ }^{17}$ ".

Destarte, não há espaço para a divisão em “parte boa” e “parte podre” da empresa deixando o passivo trabalhista com a parte podre.

\footnotetext{
${ }^{16} 33^{\circ}$ VT/R, RT 1053-2006-033-01-00-7, sentença, Juiz Titular Múcio Nascimento Borges , 30 ago, 2006.

${ }^{17}$ Ibid.
} 


\title{
4.3 - Sucessão trabalhista e o princípio da continuidade do emprego e da empresa:
}

Os princípios da continuidade do emprego e da empresa por óbvio possuem vinculação à empresa e a inserção do trabalhador na sua estrutura produtiva, sempre em atenção ao trabalho humano e a garantia de pleno emprego. Devem estar balizados também no elenco dos direitos sociais no art. $6^{\circ}$ da Carta Magna, constituindo-se garantia dos trabalhadores a proteção da relação de emprego contra a despedida arbitrária ou sem justa causa (art. $7^{\circ}$, inciso I da CRFB 88) ${ }^{18}$.

No âmbito da continuidade da atividade empresária, a LRF em seu art. 47 estabelece de forma expressa o objetivo de manutenção do emprego dos trabalhadores da empresa em processo de recuperação.

\begin{abstract}
Art. 47 da LRF: A recuperação judicial tem por objetivo viabilizar a superação da situação de crise econômico-financeira do devedor, a fim de permitir a manutenção da fonte produtora, do emprego dos trabalhadores e dos interesses dos credores, promovendo, assim, a preservação da empresa, sua função social e o estímulo à atividade econômica.
\end{abstract}

O princípio da continuidade da empresa, conforme ORLANDO GOMES e ELSON GOTTSCHALK ${ }^{19}$ :

"concretiza-se na regra de que as alterações relativas à pessoa do empreendedor não atingem o contrato de trabalho e, na outra, segundo o qual o contrato de trabalho se extingue com a dissolução da empresa. A idéia diretriz é de que a empresa constitui uma universalidade cujos elementos podem mudar sem que a unidade do conjunto seja alterada. O único elemento que variando pode fragmentar a unidade da empresa é o intelectual, isto é, o fim da empresa. (...)

\footnotetext{
${ }^{18}$ Convém mencionar a jurisprudência pacificou entendimento de que este dispositivo não é autoaplicável, ou seja, não assegura - até que seja regulamentado por lei complementar - qualquer garantia de emprego. Neste particular compartilhamos da doutrina de Maurício Godinho Delgado (Op. Cit.) para o qual: "Entretanto esta pacificação não retira do preceito constitucional a natureza de norma de eficácia contida, isto é, norma que produz, no plano da ordem jurídica, como se sabe, certo patamar, ainda que mínimo, de repercussões jurídicas. Entre essas repercussões está a de manter como regra geral, no Direito Brasileiro, o princípio da continuidade da relação de emprego (...)”. (pag. 580).

${ }^{19}$ GOMES, Orlando; GOTTSCHALK, Elson. Curso de Direito do Trabalho, 18 ${ }^{a}$. Edição, RJ, Ed. Forense. (pag 106)
} 
Mas quando o novo empregador continua na exploração nas mesmas condições em que seu predecessor, a unidade econômica e social que constitui a empresa permanece a mesma".

Como corolário necessário temos que a personalidade do empregador é indiferente para a empresa de que é titular, ou seja, esta é a essência do princípio da despersonalização do empregador. Dele extraímos que o empregador se apresenta de forma impessoal, ou seja, nenhum empecilho legal existe para que o mesmo seja substituído ou sua estrutura jurídica seja alterada, permanecendo intactos os contratos de trabalho originários. Com efeito, a pessoalidade é requisito do contrato de trabalho em relação ao empregado (art. $3^{\circ}$ da CLT), não em relação ao empregador.

Isto significa que:

"a separação de bens, obrigações e relações jurídicas de um complexo empresarial, com o fito de se transferir parte relevante dos ativos saudáveis para outro titular (direitos, obrigações e relações jurídicas), preservando-se o restante dos bens, obrigações e relações jurídicas no antigo complexo - agora significativamente empobrecido- afeta, sim, de modo significativo, os contratos de trabalho, produzindo a sucessão trabalhista com respeito ao novo titular (art. 10 e $448 C L T)^{20}$,.

\section{4 - Polêmica entre art. 60, § único versus art. 141, II (LRF):}

A questão central do argumento defendido no presente estudo gira em torno da análise das interpretações possíveis acerca da sucessão trabalhista na recuperação judicial. A matéria tratada é das mais árduas e controvertidas, havendo ponto de vista para todos os paladares, num semnúmero de opiniões as mais contraditórias, uma verdadeira "Torre de Babel”. O ponto nevrálgico da celeuma é a previsão do art. 60, parágrafo único da LRF, o qual nada menciona acerca da sucessão trabalhista,

\footnotetext{
${ }^{20}$ Sentença prolatada pelo juiz Múcio Nascimento Borges, titular da $33^{\circ} \mathrm{VT} / \mathrm{RJ}$ - processo 1053 2006-033-01-00-7.
} 
dispondo apenas sobre a responsabilidade do arrematante nas obrigações e as de natureza tributária.

Art. 60 da LRF: Se o plano de recuperação judicial aprovado envolver alienação judicial de filiais ou de unidades produtivas isoladas do devedor, o juiz ordenará a sua realização, observado o disposto no art. 142 desta lei, e ainda:

Parágrafo único: $O$ objeto da alienação estará livre de qualquer ônus e não haverá sucessão do arrematante nas obrigações do devedor, inclusive as de natureza tributária, observado o disposto no $\S 1^{\circ}$ do art. 141 desta lei.

Ainda no esforço de compreender de maneira adequada as bases do problema, mais um argumento que reforça a tese da aplicação da sucessão trabalhista no caso de recuperação judicial reside no fato de que para o caso de falência, o legislador previu expressamente que haveria exclusão do instituto da sucessão trabalhista, conforme a inteligência do art. 141, II, da LRF:

Art. 141 da LRF: Na alienação conjunta ou separada de ativos, inclusive da empresa ou de suas filiais, promovida sob qualquer das modalidades de que trata este artigo:

II - o objeto da alienação estará livre de qualquer ônus e não haverá sucessão do arrematante nas obrigações do devedor, inclusive as de natureza tributária, as derivadas da legislação do trabalho e as decorrentes de acidente do trabalho.

Diante da redação do art. 60 § único da LRF, doutrinadores digladiam-se discorrendo acerca interpretação apropriada para o referido dispositivo, justificando suas posições ora com argumentos de ordem econômica, ora jurídicos e por vezes no plano da ideologia.

$\mathrm{Na}$ metodologia empregada neste trabalho, dividiremos a argumentação nestes três níveis, e pontuaremos as supostas incompletudes e fragilidades de coerência em que incorrem os que aduzem a exclusão da sucessão trabalhista na alienação de unidade produtiva em caso de recuperação judicial, cujo caso mais emblemático é o da empresa Varig. Frise-se que a escolha por tal método de trabalho busca fazer um contraponto ao discurso dominante (exclusão da sucessão trabalhista), 
meramente para fins de problematizar a questão e levantar debates, afinal, vale destacar que este é o maior objetivo deste trabalho monográfico. $\mathrm{Na}$ medida em que o julgamento do STF decida a questão, a discussão sobre o tema perde, ao menos parcialmente, objeto e significação no plano prático.

Contudo, no plano acadêmico, sua importância permanece e certamente o debate lança luzes sobre novas possibilidades de conflitos análogas. Válido, portanto, o apanhado geral dos argumentos das principais teses em debate neste conflito.

\section{5 - Argumentos Jurídicos:}

No âmbito jurídico, a pedra angular da argumentação favorável à exclusão do ônus da sucessão trabalhista em caso de recuperação judicial está baseada, fundamentalmente, no princípio da preservação da empresa (art. 47 da LRF) mencionado alhures. A idéia é simples, mantendo-se a atividade econômica, conseguintemente, a fonte produtora de emprego dos trabalhadores também será mantida.

Para reavaliar esta lógica de pensamento, trazemos à baila dois importantes conceitos do mestre FABIO ULHOA COELHO ${ }^{21}$, quais sejam,

\footnotetext{
${ }^{21}$ COELHO, Fábio Ulhoa, Comentários à nova lei de falência e recuperação de empresas, $5^{\circ}$ edição, RJ, Ed. Saraiva, 2008, pag. 116 e 117. Registre-se que, sem embargo destas considerações iniciais do autor, o mesmo posiciona-se de modo favorável a exclusão da sucessão trabalhista. Oportuno, portanto transcrever o trecho da obra em que faz a defesa mais emblemática a respeito:

"Transcorria normalmente a audiência pública para a discussão do projeto de Lei de Falências na Comissão de Assuntos Econômicos do Senado, naquela manhã chuvosa de 3 de fevereiro de 2004. Diversos senadores, inclusive não integrantes da CAE, lotavam o auditório. Era a única reunião pública no Senado naquele momento, e estava no fim o período de convocação extraordinária no Congresso. O Presidente da Federação dos Bancos, Gabriel Jorge Ferreira, já havia falado, destacando a importância da medida na agenda microeconômica de reformas reclamadas pela economia nacional. Era minha vez de falar. Preocupado com a ruindade do projeto vindo da Câmara, eu procurava sensibilizar os senadores para a urgente necessidade de melhorar diversos aspectos da propositura. Temperava, contudo, minhas críticas destacando os pontos que considerava positivos. O auditório me ouvia em silêncio, embora um ou outro senador parecesse bem desinteressado.

Quando disse, numa passagem brevíssima e completamente marginal no meu argumento, que um dos pontos positivos do projeto era a expressa previsão de inexistência de sucessão na
} 
a idéia de que a recuperação da empresa é um valor relativo e a "solução de mercado”. Nas palavras do autor:

"A recuperação da empresa não deve ser vista como um valor jurídico a ser buscado a qualquer custo. Pelo contrário, as más empresas devem falir para que as boas não se prejudiquem. Quando o aparato estatal é utilizado para garantir a permanência de empresas insolventes inviáveis, opera-se uma inversão inaceitável: o risco da atividade empresarial transfere-se do empresário para os seus credores".

\section{Na esteira desta argumentação o autor complementa seu raciocínio}

\section{com o conceito de "solução de mercado" nos seguintes termos:}

"Em princípio se não há solução de mercado para a crise de determinada empresa, é porque ela não comporta a recuperação. Se nenhum empreendedor ou investidor viu nela uma alternativa atraente de investimento, $e$ a recapitalização e a reorganização do negócio não estimulam nem mesmos os seus atuais donos, então o encerramento da atividade, com a realocação dos recursos nela existentes, é o que mais atende à economia. Quando não há solução de mercado, aparentemente não se justificaria a intervenção do Estado (Poder Judiciário) na tentativa de recuperação da empresa. O próprio instituto jurídico da recuperação judicial parece, prima facie, um despropósito no sistema

hipótese de venda judicial da empresa do falido, alguns senadores interromperam-me com estranheza e até mesmo com certa indignação. Eu dissera que a expressa previsão de inexistência da sucessão possibilitaria atender melhor aos interesses dos credores, e a idéia lhes pareceu contraditória. Surpreendeu-me a reação da audiência. Percebi que o argumento precisava ser mais bem esclarecido, porque tinha mesmo a aparência de um contra-senso; mas não conseguia criar a chance para isso no meio ao ligeiro tumulto que se criara, com diversos senadores falando simultaneamente. Às tantas, um deles me perguntou enfático: "O senhor recomendaria essa solução para o caso Encol?” Minha resposta, após uma rapidíssima e ensaiada pausa, foi firme: "Eu recomendaria essa solução para qualquer empresa falida". Fez-se silêncio, de novo. Mesmo os senadores que me pareceram desinteressados no início, ficaram atentos.

Pude, então, construir meu argumento, sustentando que a expressa exclusão era indispensável para que surgissem interessados na aquisição da empresa do falido. Se o adquirente se torna sucessor, ele provavelmente mergulha na mesma situação patrimonial crítica que havia causado a falência do titular anterior do negócio. Ocorrem duas quebras, em vez de uma. E os credores acabam não sendo atendidos do mesmo jeito. Se a lei imputasse ao adquirente da empresa do falido as mesmas obrigações deste, os recursos da massa não seriam otimizados; haveria em decorrência, menos dinheiro para satisfazer os credores.

Honestamente, achei que não os tinha convencido. A separação entre "empresa boa" $e$ "empresa ruim", para vender a primeira a empresários capazes de mantê-la e atender os credores apenas com os recursos da segunda é expediente que parece injusto e ardiloso. Sabendo, porém, que argumentos técnicos não derrubam preconceitos sem algum tipo de maturação, saí da audiência pública receoso de que um dos poucos pontos positivos do projeto oriundo da Câmara corria o sério risco de se perder.

Fiquei, por isso, muito feliz quando vi que substitutivo Tebet aprovado pela CAE não só mantinha a expressa previsão de inexistência de sucessão, como oportunamente reforçava.

Registro essa história porque, agora, o argumento técnico em favor da inexistência de sucessão tem outros preconceitos a vencer e penso que o relato possa ser útil na empreitada (pags. 366 e 367). 
econômico capitalista. Se ninguém quer a empresa, a falência é a solução do mercado, e não há por que se buscar à força a sua recuperação”.

MARCELO PAPALÉO ${ }^{22}$ também traz luz à reflexão ao destacar os esclarecedores requisitos da “empresa viável” e “devedor honesto”. Essencialmente, assevera que:

"não se pode perder a noção de que deve ser tentada a recuperação somente de empresas viáveis e de devedores honestos, pois estes podem realmente estar debilitados economicamente, alheios à culpa ou dolo no manejo do crédito”.

Insta salientar que a própria atividade econômica foi vinculada por nossa Constituição, à produção de justiça social e que o valor social do trabalho é um dos fundamentos da República (art $1^{\circ}$, IV, CRFB/88). Por mais razões que existam para a preservação de uma empresa, não é possível fazê-la aniquilando direitos fundamentais de nosso ordenamento jurídico.

Ademais, o art. 47 da LRF defende, outrossim, a força de trabalho, um dos principais fatores de produção. Desta feita, não se pode suprimir a garantia do cumprimento das obrigações trabalhistas, sob pena de se retirar uma das peças principais da função social da propriedade.

\footnotetext{
${ }^{22}$ SOUZA, Marcelo Papaléo de; A nova lei de recuperação e falência e as suas conseqüências no Direito e no Processo do Trabalho, $2^{\mathrm{a}}$ edição, SP. Ed. Ltr, 2006 (pg. 139). Cumpre advertir que sem embargo destas considerações iniciais do autor, o mesmo posiciona-se de modo favorável a exclusão da sucessão trabalhista. Transcreve-se portanto os principais trechos desta defesa (pg 194 e 195):

"A limitação da aplicação do art. 448 da CLT, que assegura todos os direitos dos trabalhadores (previstos na Constituição Federal art. $7^{\circ}$ ) em face do sucessor, tratando-se de empresas em recuperação judicial e falidas, não é ilegal. Na aquisição de qualquer bem, o interessado, via de regra, avalia os fatores que possam diminuir o valor do negócio. Se no caso da alienação da empresa, ou estabelecimento, ocorrer a transferência das obrigações, o seu valor sofrerá redução correspondente a estas. É difícil mensurar com precisão a totalidade das dívidas do devedor, ocorrendo um superdimensionamento destas, podendo gerar o desinteresse no negócio. Portanto, partindo da inexistência da sucessão do ônus, haverá a maximização do ativo, ou seja, será alcançado valor superior, favorecendo não somente o devedor, mas também aos credores, haja vista a possibilidade de satisfação dos débitos. (...)

O que se indaga é se a restrição do direito do trabalhador e dos demais credores poderia ser de forma menos gravosa? Acredita-se que não. Não se verifica medida menos gravosa e concomitantemente apta a realizar ou alcançar o resultado pretendido. (...)

Assim, concluímos que prevalece o entendimento esposado no art. 60, parágrafo ;único da LRF, também com relação ao credor trabalhista, no sentido da inexistência da sucessão do empregador. (...) Ressalta-se que, no caso da recuperação judicial, o devedor continua a existir, tendo responsabilidade pelo pagamento de todos os direitos dos seus empregados. Só não se admite que o empregados que trabalhavam no estabelecimento alienado, em decorrência do plano de recuperação judicial, exijam do arrematante os valores anteriores à alienação".(grifos nossos)
} 
A segunda grande frente argumentativa jurídica concentra-se na defesa de que, de certo modo, é plenamente possível depreender do art. $60 \S$ único da LRF a isenção da sucessão trabalhista. Neste sentido, SÉRGIO $\mathrm{CAMPINHO}^{23}$, ao defender este ponto de vista aduz que apesar da omissão, a isenção é ampla e abarca todas as obrigações, inclusive aquelas de natureza trabalhista. Nas palavras do autor:

"Interessante questão poderá surgir na exegese desse parágrafo único do art. 60, consistente em saber se haverá ou não sucessão do arrematante nas obrigações de natureza trabalhista.

Em preceito correspondente no âmbito da falência (inciso II, do art. 141), há a menção expressa de exclusão da sucessão quanto às obrigações derivadas da legislação do trabalho e às decorrentes de acidente de trabalho, ao lado das de cunho tributário, o que não ocorre no preceito em tela.

Apesar da omissão, sustentamos que a isenção quanto à sucessão é ampla e atinge todas as obrigações, inclusive aquelas de feição trabalhista. O texto ao referir tão-somente às obrigações de natureza tributária, traduz uma oração explicativa. Qualquer limitação de obrigação deveria ser expressa”.

Apenas para rememorar:

Art. 60 da LRF: "Se o plano de recuperação judicial aprovado envolver alienação judicial de filiais ou de unidades produtivas isoladas do devedor, o juiz ordenará a sua realização, observado o disposto no art. 142 desta lei", e ainda:

Parágrafo único: $O$ objeto da alienação estará livre de qualquer ônus e não haverá sucessão do arrematante nas obrigações do devedor, inclusive as de natureza tributária, observado o disposto no $\S 1^{\circ}$ do art. 141 desta lei”.

A análise aprofundada da questão nos conduz ao incontestável fato de que quando o legislador pretendeu desonerar o adquirente das obrigações trabalhistas e as de natureza acidentárias, ele o fez de expressa somente na falência, conforme art. 141, II, parte final da LRF. Sendo certo que o mesmo não ocorreu para a recuperação judicial. Ou seja, na falência, o legislador foi enfático ao vedar a sucessão do arrematante nas obrigações trabalhistas do devedor. No tocante à recuperação judicial, quando o plano envolve alienação judicial de filiais ou de unidades produtivas isoladas do devedor, o legislador não foi tão emblemático. A LRF não prevê expressamente a sucessão trabalhista no caso da recuperação.

${ }^{23}$ CAMPINHO, Sérgio; Falência e recuperação de empresa: o novo regime da insolvência 
A inexistência de dispositivo legal que desonere o adquirente dos encargos derivados da legislação trabalhista em processo de recuperação judicial fica mais clara partindo-se para uma análise conjunta com outros dispositivos do próprio diploma legal.

No tocante às disposições gerais acerca da recuperação judicial a LRF prevê expressamente:

Art. $49 \S 2^{\circ}$ da LRF: As obrigações anteriores à recuperação judicial observarão as condições originalmente contratadas ou definidas em lei, inclusive no que diz respeito aos encargos, salvo se de modo diverso ficar estabelecido no plano de recuperação judicial.

Certo é que a parte final do art. 49 parágrafo segundo, a lei pretendeu facultar o estabelecimento de regras contrárias à sucessão e cláusulas de não responsabilização, contudo as mesmas carecem de valia perante o Direito do Trabalho.

Diante de tal previsão, em interpretação meramente literal, verificase que a lei estabelece que os adquirentes assumam as obrigações do devedor anteriores a recuperação, inclusive os encargos (pois não há qualquer exclusão aos encargos ou obrigações trabalhistas).

De outro giro, no art. 51, IX da LRF exige-se que a petição inicial da recuperação judicial seja instruída com a relação, subscrita pelo devedor, de todas as ações judiciais em que este figure como parte, inclusive as de natureza trabalhista, com a estimativa dos respectivos valores demandados. Desta maneira, é obvio que o legislador considerou os débitos judiciais trabalhistas na apuração do passivo da empresa recuperanda para efeitos de sua alienação judicial.

A rigor, ponto de interseção entre recuperação judicial e a falência é expressamente quanto à ausência de sucessão tributária e obrigacional do arrematante. 
Por outra banda, sobretudo na doutrina especializada em direito empresarial, existe a sustentação de que o art. $60 \S$ único da LRF comporta uma interpretação extensiva.

Em contrapartida, não há em tese, a possibilidade de uma interpretação extensiva do aludido preceito, a fim de justificar a vedação à sucessão trabalhista, por não ser concebível em hermenêutica atribuir a interpretação extensiva de uma norma jurídica de caráter restritivo.

Em abono a esta tese, revela-se injustificável e desarrazoada pretender a adoção de uma interpretação ampliativa e inovadora combinando-se o art. 60 parágrafo único com o art. 141, parágrafo $1^{\circ}$, pois o art. 141, II prevê que na falência (e não na recuperação judicial) o objeto da alienação estará livre de qualquer ônus e não haverá sucessão do arrematante nas obrigações do devedor, inclusive as de natureza tributária, as derivadas da legislação do trabalho.

De outro giro, CARLOS ROBERTO FONSECA ${ }^{24}$, advoga o seguinte enunciado:

"Fica evidente que a ratio legis se expressa pela total inexistência de sucessão, para quem quer que venha a adquirir seus ativos independentemente da forma adotada para a sua alienação. Prevalece o absoluto interesse na continuidade da célula social representada pelo empreendimento”.

Tal ordem de argumentação, data a máxima vênia, revela uma noção não tão clara sobre a natureza dos embates políticos no processo legislativo. Ademais, o argumento da ratio legis (ou seja, de que esta interpretação expressa o verdadeiro intuito da lei, revela a razão de ser da lei) dependendo da forma como que é aplicado, incorre na natureza do sofisma, essencialmente o falseamento do princípio da causalidade, em outras palavras, a arte de produzir efeito sem causa.

\footnotetext{
${ }^{24}$ ANDRADE, Carlos R. Fonseca. "O Direito do Trabalho e a Lei de Recuperação de Empresas"(pag. 104) In: SANTOS, Paulo Penalva (org.) "A nova Lei de Falência e de recuperação de empresas”, RJ, Ed. Forense, 2006. p. 75-107.
} 
A contra-argumentação desta ordem de idéias pode se dar pela anteriormente referida sentença do juiz da $33^{\mathrm{a}} \mathrm{VT} / \mathrm{RJ}$ Dr. Múcio Nascimento, brilhantemente fundamentada. A propósito sentença esta que certamente entrará para os anais da jurisprudência trabalhista. Prudente, portanto, beber na fonte da colenda decisão ${ }^{25}$ :

\begin{abstract}
"Meramente para fins de refutação de quaisquer dúvidas acerca da adequada interpretação do art. 60, parágrafo único devemos analisar o processo legislativo originário da LRF onde na Câmara dos Deputados o projeto apresentado pelo Poder Executivo tramitou sob o n. 4376-1993, sendo apresentado em 22/12/1993 e no Senado Federal se transmutou em projeto da Câmara n. 71-2003, tem-se que a emenda n. 12 - PLEN que PROPUNHA A EXCLUSÃO EXPRESSA DA SUCESSÃO TRABALHISTAS TAMBÉM NA RECUPERAÇÃO JUDICIAL, FOI REJEITADA, tendo prevalecido o parecer do Senador Fernando Bezerra pela seguinte justificação: A emenda n.12, do Senador Arthur Virgílio, que constitui reiteração da emenda apresentada pelo Senador Rodolfo Tourinho à Comissão de Constituição, Justiça e Cidadania, visa a modificar o parágrafo único do art. 60 do substitutivo, para estabelecer a nãoresponsabilização do arrematante pelo passivo trabalhista nas vendas judiciais de empresas no âmbito da recuperação judicial, ou seja, propõe o fim da sucessão trabalhista também na recuperação judicial.

Nosso parecer é pela rejeição da emenda, porque a exclusão da sucessão trabalhista na recuperação judicial pode dar alguma margem a fraudes aos direitos dos trabalhadores e a comportamentos oportunistas por parte dos empresários.

Além disso, é preciso ressaltar que, diferentemente do crédito tributário, protegido ao menos pela certidão negativa ou positiva com efeito de negativa para a concessão da recuperação judicial, o crédito trabalhista fica desguarnecido caso a empresa seja vendida e o valor apurado seja dissipado pela administração da empresa em recuperação judicial, já que não há, na recuperação judicial, ao contrário da falência, vinculação ou destinação específica desses valores". (grifos nossos).
\end{abstract}

A sentença vai além:

“não resta qualquer dúvida que a LRF, SOB QUALQUER INTERPRETAÇÃO, LITERAL, RESTRITIVA, E PRINCIPALMENTE TELEOLÓGICA, NÃO ISENTA O ARREMATANTE DE EMPRESA EM RECUPERAÇÃO JUDICIAL DA SUCESSÃO TRABALHISTA, a própria Casa Legislativa quando se propôs a exclusão da sucessão trabalhista no processo de recuperação judicial através da emenda 12-PLEN, rejeitou a proposição, prevalecendo a responsabilidade do arrematante pelos créditos trabalhistas da empresa em recuperação judicial”.

Inteiramente bizantina, portanto, a discussão acerca da ratio legis como justificadora na exclusão da sucessão do passivo trabalhista. Mais ainda, não se trata meramente de Mens legislatore, não cabe o velho

\footnotetext{
${ }^{25}$ 33º VT/RJ, RT 1053-2006-033-01-00-7, sentença, Juiz Titular Múcio Nascimento Borges.
} 
sofisma de Bismark sobre as "salsichas e leis" para desqualificar a relevância da investigação em torno do projeto da LRF. Levando-se em consideração os princípios constitucionais da hermenêutica, no presente caso trata-se antes de interpretação de natureza teleológica, tendo em vista o disposto em outros diplomas legais que compõem o ordenamento jurídico brasileiro (Constituição, Código Civil, CLT) e o próprio diploma da LRF (em consonância com o art. 49, parágrafo segundo).

A justificação do posicionamento adotado pela LRF concernente ao aludido dispositivo, é deveras necessária, visto que, o dinheiro obtido com a venda de estabelecimentos da empresa na recuperação judicial possui controle diferenciado do tratamento dado na falência, razão pela qual a exclusão da sucessão trabalhista poderia prejudicar os trabalhadores. Grosso modo, o preço pago pelos ativos fica à disposição da adquirente para, segundo seus interesses e conveniências, alocar os escassos recursos da forma que melhor lhe aprouver, por vezes utilizando-o nos gastos da continuação da atividade econômica que assumirá.

\section{6 - Argumentos Econômicos:}

O mais elementar e intuitivo dos argumentos pode ser reduzido na máxima: “mantenha-se o negócio e o emprego será preservado”, uma vez que sem empresa não há contrato de trabalho e nem mesmo trabalho.

Todavia, tal raciocínio não é um axioma imutável aplicável em todos os casos. Nem sempre este enunciado se torna viável. Apenas a título ilustrativo, isto não se deu no caso Varig, pois milhares de postos de trabalhos foram extintos mesmo após ter sido deferida a recuperação. A LRF trouxe sob o nobre mas falso pretexto de manutenção de empregos alguns dispositivos severamente contrários aos princípios de valorização do trabalho. 
Ainda no tocante à linha economicista, há vozes na doutrina que revelam temer pelo exaurimento do instituto (no caso da recuperação) caso ocorra a sucessão do passivo das dívidas trabalhistas, alegando que ocorreria um verdadeiro esvaziamento do ativo para pagar este tipo de credores. Trocando em miúdos, a tese central é a de que o "estímulo legal” do instituto da recuperação reside justamente na eliminação da sucessão.

Em decisão interlocutória na vara empresarial o juiz Dr. LUIZ ROBERTO AYOUB ${ }^{26}$ bem expressa esta apreensão nos seguintes termos:

“É questão principiológica que tem na manutenção da unidade produtiva sua fonte inspiradora. Exatamente debruçado neste princípio, todas as decisões são tomadas, sob pena de esvaziar a pretensão legal e, conseqüentemente, torná-la pouco atrativa, prejudicando o desenvolvimento do nosso país.(...)

O propósito da lei reside em criar cenário de atratividade para garantir e estimular o surgimento do crédito. Do contrário, essa importante legislação a ninguém servirá, lamentavelmente. (...)

Entenda-se, inclusive, que a eliminação da sucessão é a mais ampla possível. Não só a de natureza fiscal, mas também aquelas de feição trabalhista".

Em recente artigo $^{27}$, o magistrado reforça e esclarece eficazmente os argumentos ligados ao novo cenário de estímulos e atrativos:

"Com efeito, a leitura do art. 75 da LRF revela a intenção do legislador em manter, sempre que possível, a atividade empresarial. (...) É, portanto, uma lei pintada com tintas jurídicas e econômicas que procura viabilizar o funcionamento de empresas. (...) O extermínio da atividade empresarial só se justifica quando se mostrar nociva à sociedade. Do contrário, a todos interessa a sua existência. É o sucesso da lei que dependerá, por certo, da correta interpretação dos seus aplicadores. (...).

Com efeito, a nova disciplina legal é marcada por estímulos e atrativos que importam em garantir o surgimento do crédito, tão escasso entre nós, e barateálo, através de garantias que importem sensibilizar o investidor".(grifos nossos)

Ainda no âmbito da construção jurisprudencial, neste sentido, a juíza trabalhista FERNANDA STIPP ${ }^{28}$ assevera:

\footnotetext{
26 Decisão prolatada pelo juiz Luiz Roberto Ayoub, titular da $01^{\circ} \mathrm{VE} / \mathrm{RJ}-$ processo $\mathrm{n}^{\circ}$ 2005.001.072887-7 Rio de Janeiro, 05 jun, 2006.

${ }^{27}$ AYOUB, Luiz Roberto. Recuperação de empresas: uma lei de estímulos e atrativos - Reflexões gerais. Revista da Escola Nacional da Magistratura - Associação dos Magistrados Brasileiros. Ano III, n 5, p. 90 - 103, Maio de 2008.

28 Sentença proferida pela juíza substituta trabalhista Fernanda Stipp, da 19a VT/RJ, - RT 17252006-019-01-00-8, Rio de Janeiro, 06 out, 2007.
} 


\begin{abstract}
"O que pretendeu o legislador indubitavelmente foi garantir o adquirente. Assim, o comprador em leilão sabe que as unidades produtivas ali dispostas não tem qualquer dívida ou obrigação inadimplida, o que garante não só melhores condições de mercado para aquelas empresas, como também um mecanismo de pacificação social. $O$ adquirente sabe o que está comprando, quanto está gastando e exatamente quanto ainda vai ter que desembolsar para o desenvolvimento da atividade empresarial que está sendo adquirida.

Ressalte-se que garantir a ausência de ônus sobre a empresa alienada importa em aumento do valor de venda das unidades produtivas. Assim, garante-se que estas possam alcançar valores bastante superiores aos que alcançariam aqueles bens após a quebra, garantindo, ainda, a sobrevivência de alguns postos de trabalho, minimizando o desemprego que anteriormente seria inevitável, bem como garantindo o recebimento de algum valor aos desligados, e quem sabe, da integralidade de seus créditos, ante todo o cumprimento de todo o plano de recuperação judicial, em que já que fica o devedor sob o crivo da autoridade judicial até o cumprimento de todas as suas obrigações.

A venda da unidade produtiva em hasta pública na efetiva qualidade de empresa garante não só a manutenção dos postos de trabalho daquela unidade vendida, como também da própria empresa em recuperação judicial que passa a angariar com as vendas, dinheiro, para a continuidade de suas atividades e paga duas dívidas. A grande idéia que apresenta a nova legislação de falência é a efetiva proteção social, com a tentativa de minorar os estragos da quebra, garantindo aos trabalhadores empregos que anteriormente estariam extintos”.
\end{abstract}

Todavia, sobre um suposto “esvaziamento da pretensão legal” já esgotamos a análise no tópico referente a ratio legis. Movendo-se para a outra linha argumentativa, qual seja, a de que a nova legislação tem o propósito de estimular os investidores fomentando o surgimento do crédito, não podemos olvidar o preço que pagamos por tal escolha. Neste ponto deslocamo-nos do estudo especificamente do caso Varig, para nos volver em uma análise crítica da LRF como estatuto jurídico, considerando seu todo. Ocorre que, ao pensar a prática jurídica, devemos ter os olhos lavados pela realidade. A impossibilidade de um rigoroso controle judicial no caso de recuperação judicial faz com que, como acima aduzido, o dinheiro obtido com a venda de estabelecimentos da empresa fique à disposição da empresa adquirente para gerí-lo de forma que lhe aprouver. Caso o dinheiro arrecadado e reinjetado na empresa seja mal gerido ${ }^{29}$, existe a real possibilidade da empresa não se reerguer, perdendo-se estes valores.

\footnotetext{
${ }^{29}$ Anexo 1 - Entrevista concedida na fase de elaboração deste trabalho em 22/10/2008. Quando questionado acerca da existência de diferenças de controle judicial exercido em relação aos valores nos caso da recuperação judicial e da falência, Dr. Luiz Roberto Ayoub respondeu: "O dinheiro foi arrecadado para injetar na recuperação. Pode ser dissipado? Pode se ela mal gerir. A diferença é
} 
Para além das dificuldades inerentes ao processo tais como o fato da LRF ser recente, a importância da Varig para o país, e o enorme número de pessoas envolvidas, houve a deturpação de informações pelos setores midiáticos. A celeridade da informação no mundo das telecomunicações não acompanha o tempo da jurisdição, e por vezes, a mídia acaba por prestar um desserviço com divulgações de informações cruzadas e equivocadas, pouco contribuindo para a informar aos diversos setores da sociedade sobre o quadro real, como por exemplo, denúncias acerca das altas remunerações ${ }^{30}$ de supostos administradores judiciais nomeados, que mostraram-se falsas.

Uma das denúncias amplamente divulgada foi relativa à disputa societária da Varig Log, que se encontra sob judice. A composição acionária infringia o art. 181 da legislação aeronáutica, o qual não permite que estrangeiros exerçam o controle acionário de empresa aérea brasileira. Então três sócios brasileiros da VOLO DO BRASIL (empresa compradora da Varig Log), Marco Antônio Audi, Luiz Gallo e Marcos Haftel, de acordo com investigações, são suspeitos de terem sido usados como "laranjas" do chinês Lap Wai Chan representante do fundo de investimento norte americano Matlin Patterson.

Assim, no âmbito da análise crítica da LRF organicamente considerada, ainda que tal denúncia não possua relação direta com o processo de recuperação judicial acaba por revelar as fragilidades dos mecanismos disponíveis de controle judicial para coibir tais práticas

que na falência você realiza os ativos para pagar os credores, na recuperação você pega o dinheiro e injeta na empresa para tentar se reerguer. O que sempre ocorreu de preocupação foi o seguinte: E se a empresa não se reerguer? Perdeu-se aquilo tudo? Sim, há uma chance. Mas no caso específico da Varig se houvesse a falência, os trabalhadores não receberiam pois não havia ativo suficiente para ser liquidado(...)”.

${ }^{30} \mathrm{O}$ GLOBO, Rio de Janeiro, 14 de Maio, 2008. À guisa de exemplificação, foi noticiado que Alfredo Luiz Kugelmas, Luiz Gaj e Oscar Spessot foram nomeados fiscais e a seguir administradores da Varig em recuperação, com remuneração mensal de 200 mil reais. Por sua vez, Alfredo Luiz Kugelmas, fiscal nomeado, além disso, indicou uma pessoa para o auxiliar, o engenheiro José Cherington Neves Boarin, com remuneração mensal para a fiscalização de 75 mil reais. Sendo assim, note-se de que estas cifras potencialmente podem esvaziar o ativo da empresa, restando um forte indício de comportamento oportunista. 
societárias que visam burlar a lei. Vale destacar, no entanto que a Varig Log ao participar do leilão judicial, tinha tido sua composição acionária atestada pela ANAC, e conseguintemente, haviam tidos também as manifestações da Receita Federal e do Banco Central a respeito. Destaque-se outrossim, que a venda em leilão foi aprovada pela ANAC e pelo CADE (Conselho Administrativo de Defesa do Consumidor).

No plano prático a VarigLog demitiu 2/3 de seus funcionários, implanta um duvidoso programa de demissão voluntária, funcionários são demitidos sem receber verba rescisória e paralelamente há a destinação dos valores do ativo apurado com o soerguimento da empresa.

Entrando no mérito quanto à forma que se convencionou o pagamento dos débitos derivados da relação de emprego pela Varig SA em recuperação judicial, vale lembrar que este seria feito através de garantia de participação no capital da Unidade Produtiva Varig, na forma de debêntures com prazo de vencimento de 10 anos. Neste sentido, muito perspicaz a petição inicial da Ação Civil Pública movida pelo Ministério do Trabalho da $1^{\text {a }}$. Região, subscrita pelo Procurador do Trabalho RODRIGO CARELLI $^{31}$ presentante da instituição, insurgindo-se contra tais condições. Registrem-se as eloqüentes considerações:

\footnotetext{
"As rés não desejam pagar os trabalhadores na forma da lei, pois, além de entender não existir sucessão trabalhista, entendem que essa deverá ser paga na forma proposta no plano de recuperação judicial, com debêntures e outros créditos ilíquidos da Varig antiga. No entanto, os trabalhadores, em seus créditos extraconcursais, como são os que ao se reclama, devem aderir voluntariamente às condições do plano, o que não ocorreu, como prevê o próprio plano de recuperação judicial.

$E$ isso não ocorreu porque se aceitarem o plano como querem as rés, os trabalhadores deverão esperar anos para que haja o pagamento de créditos alimentares. Isto é impossível, injusto, injustificável e iníquo, pois o estômago não come debêntures e com estas não se faz compras no supermercado nem podem ser usadas para pagar aluguel”.
}

\footnotetext{
${ }^{31}$ Ação Civil Pública (em dependência com as ACPS no. 1053-2006-033-01-00-7 e 1065-2006033-01-00-1) subscrita pelos Procuradores do Trabalho da $1^{\text {a }}$ Região: Rodrigo de Lacerda Carelli e João Hilário Valentim.
} 
Tais condições são praticamente transferir para os empregados os encargos da atividade econômica em total afronta ao princípio da irrenunciabilidade que orienta do direito do trabalho.

A conseqüência lógica advinda deste princípio protetor é de que subsistem direitos previstos em lei que não se apresentam disponíveis e passíveis de negociação, mormente quando a pactuação se afigura totalmente prejudicial aos empregados e importa em renúncia a direitos fundamentais. O que deve sempre ser observado é se da alienação da Varig SA em recuperação judicial emergem potencialmente condições precárias ou desfavoráveis aos empregados.

Por outro lado, é pacífico na jurisprudência trabalhista frente ao princípio da irrenunciabilidade, que cláusulas que contratem de modo distinto a orientação deste vetor carece de validade. Consoante MAURÍCIO GODINHO DELGADO ${ }^{32}$ :

"a medida que o instituto sucessório é criado por normas jurídicas imperativas, torna-se irrelevante para o Direito do Trabalho a existência de cláusulas firmadas no âmbito dos empregadores envolvidos (...). À luz da CLT, tais débitos transferem-se, sim, imperativamente ao adquirente”.

Desta maneira, contratar de forma contrária é ofender, em última análise, ao ordenamento jurídico como um todo.

Sem dúvida que é justo e necessário que exista na legislação salvaguardas visando à recuperação dos devedores que eventualmente estejam em situação econômica debilitada, afastando as conseqüências prejudiciais a toda sociedade pela cessação das atividades. Afinal de contas, com a singela porém preciosa lição de Karl Marx aprendemos que "não devemos desprezar os fatos”. Entretanto, todos devem suportar sacrifícios e fazer concessões em razão da crise da empresa, e não tão somente os credores trabalhistas. O inadmissível é interpretar um dispositivo genérico contra a previsão legal expressa, para desvalorizar o trabalho e, sobretudo,

\footnotetext{
${ }^{32}$ DELGADO, Maurício Godinho, Curso de Direito do Trabalho, (pag 420)
} 
dar à atividade empresária um salvo conduto para exonerá-la de qualquer tipo de responsabilidade social pelos trabalhadores.

\section{7 - Argumentos Ideológicos:}

De modo geral, a visão que defende a exclusão da sucessão do passivo trabalhista no caso da recuperação judicial está ao fim e ao cabo comprometida com uma interpretação economicista do Direito.

A principiologia da interpretação econômica baseia-se, fundamentalmente, em três pilares, quais sejam, a liberdade individual, mercado livre e governo limitado. São interpretações que representam filiação à Teoria Econômica do Direito. Grosso modo, destinam seus estudos à demonstração empírica de que países que possuem instituições mais fortes, que asseguram os direitos de propriedade e o cumprimento de contratos, experimentam necessariamente maiores índices de crescimento do PIB (produto interno bruto) per capita e maiores taxas de investimento interno e externo

Todavia, a interpretação economicista do Direito não está imune às falácias. Disto resulta que tal orientação busca justificar as posições jurídicas pelos fins econômicos, geralmente unilaterais, pois objetiva-se tão somente a manutenção da empresa, seja a que custo for para os credores e trabalhadores. Na tentativa de se firmar como ciência, "resgata” termos econômicos tais como "blindagem”, “eficiência” e “modelo hipotético”, e apesar de seu pragmatismo não leva em consideração os milhares de trabalhadores que financiaram a Varig nos últimos meses ao trabalharem e não receberem sua devida contraprestação.

Desconsidera também os trabalhadores que são estáveis conforme o acordo coletivo, à beira da aposentadoria, e que estão sendo deixados na 
“geladeira” pela nova empresa. Será razoável deixar todas estas questões para serem solucionadas pela milagrosa mão invisível do mercado? Tais teorias não conseguem fornecer uma compreensão mais específica para casos concretos como o da Varig. Fato é que a Teoria Econômica do Direito não é capaz de suprir o legado de miséria, analfabetismo, mortalidade infantil, desemprego, a baixa capacidade de poupança e as limitadas possibilidades tecnológicas, alguns dos desafios enfrentados pelo Brasil e demais países emergentes.

No esforço da intelecção das impropriedades e limitações do discurso economicista aplicável ao Direito, resta a prudente lição de EVARISTO DE MORAES ${ }^{33}$ no clássico "Sucessão nas obrigações e a Teoria da empresa”

"O conceito econômico não se justapõe ao jurídico de modo perfeito sem deixar resto (...) Há sempre que existir uma larga margem comum, o bastante para o seu aproveitamento em planos científicos complementares. Aliás, numa sociedade organizada, os dois processos são inextricáveis, havendo sempre muito de controle jurídico-formal na organização econômica”.

Ainda no âmbito dos argumentos ideológicos, há que se destacar a necessidade de um projeto civilizatório das relações trabalhistas para a agenda governamental e, principalmente, no plano institucional.

Reconhece-se atualmente que as normas programáticas possuem um valor jurídico constitucionalmente idêntico ao dos demais preceitos da Constituição. Tais normas devem ser consideradas obrigatórias e aplicadas com objetividade, de tal sorte que seja enfatizado sempre o sentido de sua plena concretização e efetividade.

Como preleciona MARCELO $\mathrm{MAUAD}^{34}$ o princípio do Estado Democrático de Direito, densificado no preceito da socialidade também

\footnotetext{
${ }^{33}$ MORAES, Evaristo de, Sucessão nas obrigações e a Teoria da empresa, $1^{\text {a }}$ edição, RJ, Ed. Forense, 1960, pg. 331.

${ }^{34}$ MAUAD, Marcelo. Bases Constitucionais da lei de recuperação e falência: função social da empresa e os direitos dos trabalhadores. .Disponível em <http://www.unisolbrasil.org.br>. Acesso em 01 set. 2008.
} 
repercute na vedação de medidas que importem em retrocesso social. Isto significa dizer que os direitos sociais e econômicos, uma vez alcançado determinado patamar, não se admitem, em condições normais retroceder, retirar as conquistas alcançadas ou enfraquecer os direitos sociais. O referido autor em perspicaz análise da questão assevera que:

"O princípio do Estado Democrático de Direito, na sua dimensão de democracia econômica e social, deve ser densificado pelo princípio da socialidade, que, de seu turno, é concretizado pelas normas regentes de direitos econômicos e sociais. Busca-se superar o manifesto caráter individualista da lei, adotando-se mecanismos que prestigiem, principalmente, os interesses da coletividade. O que, de fato, propugna-se é que os interesses sociais prevaleçam, quando em contraste com os ganhos exclusivamente individuais”.

Desta feita, a partir do plano do Direito Laboral, evidencia-se algo mais concreto e específico, pois os direitos trabalhistas são majoritariamente considerados como de ordem pública e disto resulta que atendem ao princípio da melhoria da condição social, a proibição do retrocesso social, e o compromisso com o projeto civilizatório nas relações trabalhistas.

Importa consignar que, da reserva legal dos direitos fundamentais, resultam os limites da atuação do legislador, isto é, em que medida poderá o legislador buscar a concretização de determinados fins que justifiquem uma restrição no âmbito de proteção dos direitos fundamentais e, de outra parte, em que medida poderá utilizar a lei como meio de alcançar os fins almejados. É por esta razão que se costuma falar de uma relação entre meios e fins como integrando o princípio da proporcionalidade.

Basicamente, o princípio da proporcionalidade cuida, fundamentalmente, de aferir a compatibilidade entre meios e fins, de modo a evitar restrições desnecessárias ou abusivas contra direitos fundamentais.

Derradeiramente podemos nos valer do Princípio da Justiça, ou seja, a igualdade dos homens entre si. Há posição doutrinária firmada no sentido de que não existem maiores problemas com relação a impossibilidade de vinculação legal, e conseguintemente menor controle judicial, da destinação 
dos valores obtidos do ativo na recuperação judicial, uma vez que por expressa previsão legal (arts. 55 e 56 da LRF) o referido plano de recuperação deve ser aprovado por todos os credores por classe, tendo desta forma, sido efetivamente assegurada a ampla participação e fiscalização pelos próprios credores.

Ocorre na prática, porém, que o real sentido da negociação não chega a concretizar-se para os credores trabalhistas, frente aos interesses econômicos do grupo de credores ligados ao sistema financeiro. Mesmo unidos em classe, estes não detém paridade de força econômica e acabam por permitir toda a sorte de troca, mesmo sendo-lhes profundamente desfavorável, sendo forçados a abrir mão da integridade de seus direitos à não receber nada. Ademais, há trabalhadores que efetivamente não participaram da aprovação do plano de recuperação judicial, foram posteriormente dispensados, e que mesmo assim, estão sujeitos ao referido plano.

Conseguintemente, faz-se necessária a reflexão acerca do real significado da negociação e trocas no embate de interesses conflitantes. O filósofo ANDRÉ COMTE-SPONVILLE ${ }^{35}$ já argutamente para a questão da imprescindibilidade de igualdade para efetivação de troca com justiça. Nas palavras do mestre:

"Se procedo a uma troca que me é desvantajosa (se por exemplo troco minha casa por um pão), devo estar louco, mal informado ou forçado, o que, nos três casos, esvaziaria a troca não necessariamente de todo valor jurídico, mas, claramente, de toda justiça. A troca, para ser justa, deve efetuar-se entre iguais, ou pelo menos nenhuma diferença (de fortuna, de poder, de saber...) entre os parceiros deve lhes impor uma troca que seja contrária aos seus interesses ou a suas vontades livres e esclarecidas, tais como se exprimiriam numa situação de igualdade. (...) A justiça é a igualdade, mas a igualdade dos direitos, sejam eles juridicamente estabelecidos ou moralmente exigidos. (...) A justiça é uma condição de igualdade, à qual nossas trocas devem submeter-se”.

\footnotetext{
${ }^{35}$ SPONVILLE, André Comte. Pequeno tratado das grandes virtudes, $12^{\mathrm{a}}$ edição, SP, Ed. Martins Fontes, 2007 (pg 76).
} 
A grande contribuição de COMTE-SPONVILLE para o debate reside na parcimoniosa lição de que a igualdade em questão não é uma igualdade de fato ou de poder, mas uma igualdade de direitos, que sabemos não existir na LRF com relação aos credores trabalhistas, preteridos em relação ao mercado financeiro. 


\section{LIMITAÇÃO DOS CRÉDITOS TRABALHISTAS:}

A LRF se por um lado apresenta várias formas para resgate da viabilidade empresarial, por outro penaliza os trabalhadores limitando seus créditos privilegiados a cento e cinqüenta salários-mínimos por credor, além de conceder prazo de até um ano para a quitação de salários e verbas resilitórias, de natureza estritamente alimentar.

Art. 83. A classificação dos créditos na falência obedece à seguinte ordem:

I - os créditos derivados da legislação do trabalho, limitados a 150 (cento e cinqüenta) salários-mínimos por credor, e os decorrentes de acidentes de trabalho;

II - créditos com garantia real até o limite do valor do bem gravado;

III - créditos tributários, independentemente da sua natureza e tempo de constituição, excetuadas as multas tributárias;

IV - créditos com privilégio especial, a saber:

a) os previstos no art. 964 da Lei $n^{\circ} 10.406$, de 10 de janeiro de 2002;

b) os assim definidos em outras leis civis e comerciais, salvo disposição contrária desta Lei;

c) aqueles a cujos titulares a lei confira o direito de retenção sobre a coisa dada em garantia;

$V$ - créditos com privilégio geral, a saber:

a) os previstos no art. 965 da Lei $n^{\circ} 10.406$, de 10 de janeiro de 2002;

b) os previstos no parágrafo único do art. 67 desta Lei;

c) os assim definidos em outras leis civis e comerciais, salvo disposição contrária desta Lei;

VI - créditos quirografários, a saber

a) aqueles não previstos nos demais incisos deste artigo;

b) os saldos dos créditos não cobertos pelo produto da alienação dos bens vinculados ao seu pagamento;

c) os saldos dos créditos derivados da legislação do trabalho que excederem o limite estabelecido no inciso I do caput deste artigo;

VII - as multas contratuais e as penas pecuniárias por infração das leis penais ou administrativas, inclusive as multas tributárias; 
VIII - créditos subordinados, a saber:

a) os assim previstos em lei ou em contrato;

b) os créditos dos sócios e dos administradores sem vínculo empregatício.

$\S 1^{\circ}$ Para os fins do inciso II do caput deste artigo, será considerado como valor do bem objeto de garantia real a importância efetivamente arrecadada com sua venda, ou, no caso de alienação em bloco, o valor de avaliação do bem individualmente considerado.

$\S 2^{\circ}$ Não são oponíveis à massa os valores decorrentes de direito de sócio ao recebimento de sua parcela do capital social na liquidação da sociedade.

$\S 3^{\circ}$ As cláusulas penais dos contratos unilaterais não serão atendidas se as obrigações neles estipuladas se vencerem em virtude da falência.

$\S 4^{\circ}$ Os créditos trabalhistas cedidos a terceiros serão considerados quirografários. (grifos nossos)

Sobre a classificação dos créditos trabalhistas na falência vale destacar o posicionamento de CARLOS ROBERTO FONSECA ${ }^{36}$ o qual se mostra plenamente favorável chegando mesmo a tomar este limite por justo e razoável. Argumenta em termos matemáticos, como se segue:

\begin{abstract}
"Tem-se assistido a algumas manifestações contrárias à limitação do privilégio ao crédito trabalhista, balizando-o em valor igual a cento e cinqüenta salários mínimos na data da decretação da falência, com o argumento de que reflete uma inadmissível restrição quantitativa.

Já se registrou que a restrição ao valor dos créditos trabalhistas revela-se uma prática internacional mais severa do que a ora adotada. A par disso, estatística divulgada pelo Tribunal Superior do Trabalho no Brasil em seu Relatório Geral de Justiça do Trabalho relativo ao ano de 2003 - o de 2004 ainda não foi disponibilizado - revela dados que devem ser considerados para um avaliação do limite imposto ao privilégio do crédito trabalhista.

Assim é que os números informam que, no ano de 2003, foram encerrados no âmbito da Justiça do Trabalho, em todo o território nacional, 1.535 .550 processos. Desses, 725.975 por acordo, 53.691 por desistência, 209.931 por arquivamento e 545.953 por execução finda. Informa, ainda, o relatório que foi aos reclamantes o valor total de $R \$ 5.038 .809 .649,29$ (cinco bilhões, trinta e oito milhões, oitocentos e nove mil, seiscentos e quarenta e nove reais e vinte e nove centavos). Excluídas as desistências e os arquivamentos que não geraram pagamentos e somando-se os processos encerrados por acordo ou com execução concluída, atingem estes o número de 1.271 .928 processos que justificam o total pago.

A conta é simples: dividindo-se o valor pago aos reclamantes pelo número de processos em que houve pagamento, chega-se à conclusão de que, naquele caso, o valor médio dos processos foi de $R \$ 3.961,00$ ou cerca de dezessete salários
\end{abstract}

\footnotetext{
${ }^{36}$ ANDRADE, Carlos R. Fonseca. O Direito do Trabalho e a Lei de Recuperação de Empresas (pag. 98) In: SANTOS, Paulo Penalva (org.) "A nova Lei de Falência e de recuperação de empresas", RJ, Ed. Forense, 2006. p. 75-107.
} 
mínimos, considerando-se que em abril do ano de 2003, o salário fixado em lei foi de $R \$ 240,00$ (duzentos e quarenta reais). A conclusão que se extrai é a de que é socialmente justo e razoável o limite fixado para o privilégio no valor igual a cento e cinqüenta salários mínimos. O limite reveste-se de princípios éticos, sociais e operacionais”.

FABIO ULHOA COELHO ${ }^{37}$ preleciona a justificativa da limitação na preferência dos créditos trabalhistas em função do esgotamento dos recursos da massa falida. Nas palavras do autor:

\begin{abstract}
"Atente-se que nem todos os créditos de natureza trabalhista gozam desse grau de preferência no concurso falimentar. A lei estabelece um limite, ao definir os créditos dessa classe. O limite é de 150 salários mínimos por credor. Quer isso dizer que o empregado com crédito inferior ou igual a esse limite concorre nessa classe preferencial pela totalidade de seu direito; mas aquele que possui crédito maior que o teto indicado participa do concurso em duas classes: pelo valor de 150 salários mínimos na dos empregados e equiparados e pelo que exceder, na dos quirografários.

O objetivo da limitação é impedir que se consumam os recursos da massa com o atendimento a altos salários dos administradores da sociedade falida. A preferência da classe dos empregados e equiparados é estabelecida com vistas a atender os mais necessitados, e os credores por elevados salários não se consideram nessa situação".
\end{abstract}

O problema central desta argumentação é que não se sustenta a mais rasa inquirição das bases materiais que lhe dão suposta coerência. Quedamse verdadeiras falácias, o arquétipo do "canto da sereia" ao aduzir o engodo acerca do exaurimento dos recursos da massa falida. Conjuremos, pois o exemplo de Ulisses, prudente em sua jornada preparou-se para os males que estavam por vir, tapando os ouvidos ao mortal "canto da sereia", seguindo firme a conduzir sua tripulação a salvo dos perigos.

Considerando-se a falência da atividade empresária, nos moldes da LRF, na prática, diversos outros compromissos serão pagos previamente ao elenco do art. 83 da LRF. Belíssima e esclarecedora a contribuição de MARCELO MAUAD ${ }^{38}$ para a desconstrução desta linha argumentativa, deixando claro que a ênfase do novo diploma privilegia o capital em

\footnotetext{
${ }^{37}$ COELHO, Fábio Ulhoa, Comentários à nova lei de falência e recuperação de empresas, pag. 214 e 215.

${ }^{38}$ MAUAD, Marcelo. Bases Constitucionais da lei de recuperação e falência: função social da empresa e os direitos dos trabalhadores .Disponível em <http://www.unisolbrasil.org.br>. Acesso em 01 set. 2008.
} 
detrimento do trabalho em razão da crise da empresa. Após uma leitura pormenorizada e atenta da LRF, percebe-se que o art. 83 vale bem menos do que se possa imaginar. E assim sendo:

“É fora de dúvida que a LRF, efetivamente, privilegia o adimplemento das obrigações devidas ao Sistema Financeiro em razão da crise da empresa. Primeiro, porquanto autoriza o adimplemento de obrigações financeiras, antes mesmo de iniciar o rateio previsto no art. 83, a saber:

a) Prevalecem as obrigações assumidas no âmbito das câmaras prestadoras de serviço de compensação e de liquidação financeira (Arts. 193 e 194, da LRF), regidas por regulamentos específicos;

Art. 193. O disposto nesta Lei não afeta as obrigações assumidas no âmbito das câmaras ou prestadoras de serviços de compensação e de liquidação financeira, que serão ultimadas e liquidadas pela câmara ou prestador de serviços, na forma de seus regulamentos.

Art. 194. O produto da realização das garantias prestadas pelo participante das câmaras ou prestadores de serviços de compensação e de liquidação financeira submetidos aos regimes de que trata esta Lei, assim como os títulos, valores mobiliários e quaisquer outros de seus ativos objetos de compensação ou liquidação serão destinados à liquidação das obrigações assumidas no âmbito das câmaras ou prestadoras de serviços.

b) São mantidas e realizadas operações como compensação e liquidação de obrigações no âmbito do Sistema Financeiro Nacional, nos termos da legislação vigente, não obstante a decretação de quebra da empresa (Art. 119, inciso VIII da LRF);

Art. 119. Nas relações contratuais a seguir mencionadas prevalecerão as seguintes regras:

VIII - caso haja acordo para compensação e liquidação de obrigações no âmbito do sistema financeiro nacional, nos termos da legislação vigente, a parte não falida poderá considerar o contrato vencido antecipadamente, hipótese em que será liquidado na forma estabelecida em regulamento, admitindo-se a compensação de eventual crédito que venha a ser apurado em favor do falido com créditos detidos pelo contratante.

c) Os adiantamentos de contratos de câmbio para exportação são considerados como restituições (art. 86, inciso II, da LRF) e, portanto, os respectivos interessados recebem antes dos credores elencados nos arts. 83 e 84 da LRF;

Art. 86. Proceder-se-á à restituição em dinheiro:

II - da importância entregue ao devedor, em moeda corrente nacional, decorrente de adiantamento a contrato de câmbio para exportação, na forma do art. 75 , $\S \S 3^{0}$ e $4^{0}$, da Lei $n^{0} 4.728$, de 14 de julho de 1965 , desde que o prazo total da operação, inclusive eventuais prorrogações, não exceda o previsto nas normas específicas da autoridade competente. 
d) Os créditos financeiros enquadrados como extraconcursais (art. 84) também são pagos antes dos concursais previstos no art. 83.

Art. 84. Serão considerados créditos extraconcursais e serão pagos com precedência sobre os mencionados no art. 83 desta Lei, na ordem a seguir, os relativos a:

I - remunerações devidas ao administrador judicial e seus auxiliares, e créditos derivados da legislação do trabalho ou decorrentes de acidentes de trabalho relativos a serviços prestados após a decretação da falência; II - quantias fornecidas à massa pelos credores;

III - despesas com arrecadação, administração, realização do ativo e distribuição do seu produto, bem como custas do processo de falência;

IV - custas judiciais relativas às ações e execuções em que a massa falida tenha sido vencida;

$\mathrm{V}$ - obrigações resultantes de atos jurídicos válidos praticados durante a recuperação judicial, nos termos do art. 67 desta Lei, ou após a decretação da falência, e tributos relativos a fatos geradores ocorridos após a decretação da falência, respeitada a ordem estabelecida no art. 83 desta Lei.

Ademais as obrigações devidas a credor por alienação fiduciária, credor por arrendamento mercantil, credor por contratos de reserva de domínio, dentre outros, não se submetem aos efeitos da recuperação judicial, prevalecendo as condições contratuais originárias (art. 49, parágrafo 3, da LFR)

Art. 49. Estão sujeitos à recuperação judicial todos os créditos existentes na data do pedido, ainda que não vencidos.

$\S 3^{0}$ Tratando-se de credor titular da posição de proprietário fiduciário de bens móveis ou imóveis, de arrendador mercantil, de proprietário ou promitente vendedor de imóvel cujos respectivos contratos contenham cláusula de irrevogabilidade ou irretratabilidade, inclusive em incorporações imobiliárias, ou de proprietário em contrato de venda com reserva de domínio, seu crédito não se submeterá aos efeitos da recuperação judicial e prevalecerão os direitos de propriedade sobre a coisa e as condições contratuais, observada a legislação respectiva, não se permitindo, contudo, durante o prazo de suspensão a que se refere o $\S 4^{0}$ do art. $6^{-}$desta Lei, a venda ou a retirada do estabelecimento do devedor dos bens de capital essenciais a sua atividade empresarial.

E acresce, ainda, que a LRF autoriza os pagamentos de juros das debêntures e dos créditos com garantia real (art. 124, parágrafo único), como tratamento privilegiado eis que se constitui na única exceção da lei a autorizar o pagamento de juros (caput do art. 124)".

Art. 124. Contra a massa falida não são exigíveis juros vencidos após a decretação da falência, previstos em lei ou em contrato, se o ativo apurado não bastar para o pagamento dos credores subordinados.

Parágrafo único. Excetuam-se desta disposição os juros das debêntures e dos créditos com garantia real, mas por eles responde, exclusivamente, o produto dos bens que constituem a garantia. 
Também aderindo à contracorrente, sustentando a inconstitucionalidade do art. 83, I da LRF, insta consignar a posição de JOAQUIM PENALVA SANTOS ${ }^{39}$, para quem “também não nos parece certa a limitação de tais créditos a cento e cinqüenta salários mínimos, por prejudicar o empregado que, após muitos anos de casa, elevando-se a nível alto na hierarquia da empresa, faz jus a essa remuneração”.

Nesta mesma ordem de idéias irretocável a sagaz percepção de SERGIO CAMPINHO ${ }^{40}$, desvelando mais uma faceta do engodo fruto da incoerência da limitação dos créditos trabalhistas:

"O intento da lei foi o de não atender com preferência absoluta àqueles créditos provenientes de altos salários detidos por administradores ou empregados graduados. A perspectiva não nos pareceu irradiadora de eqüidade, eis que créditos trabalhistas também o são. O empregado que ganha muito ou pouco, não importa, deve ser considerado como empregado. Os direitos sociais a serem atendidos têm tronco comum. Eventual fraude verificada, por exemplo, com a elevação artificial de salários de pessoas ligadas aos controladores da sociedade, expediente engendrado com o fim de reativar valores da massa, dada a prioridade no pagamento dentro do concurso falimentar, deveria ser atacada por remédios próprios. A possível existência desse mecanismo fraudulento foi por muitos, na fase da elaboração legislativa, suscitada para a consagração do limite. Há, para nós, um equívoco. A fraude não se presume. Deve ser comprovada. São os probos punidos, porque o legislador constrói um sistema defensivo, que inverte conceitos. Parte da presunção de quem aufere um bom salário não deve ser com preferência atendido, porque o fato deveria revelar manobra capaz de subtrair recursos da massa, destinados ao pagamento de outros credores. Isso nos parece um absurdo”.

No tocante à limitação dos créditos trabalhistas disciplinada no art.

83, I da LRF, insta consignar outras importantes considerações. Examinando os termos do art.449 da CLT temos:

\footnotetext{
Art. 449 - Os direitos oriundos da existência do contrato de trabalho subsistirão em caso de falência, concordata ou dissolução da empresa

$\S 1^{\circ}$ - Na falência, constituirão créditos privilegiados a totalidade dos salários devidos ao empregado e a totalidade das indenizações a que tiver direito.
}

\footnotetext{
39 SANTOS, Joaquim de V. Penalva, Recuperação judicial de empresas, 2007, $1^{\mathrm{a}}$ edição, RJ, Ed. Espaço Jurídico, 2007 (pg. 105).

40 CAMPINHO, Sérgio; Falência e recuperação de empresa: o novo regime da insolvência empresarial, pags. 394 e 395.
} 
Ou seja, consoante o regramento da CLT, na falência constituirão créditos privilegiados a integralidade (totalidade) dos salários e indenizações devidas ao empregado. Estão, pois lançadas as bases do problema. Portanto, há que se estabelecer qual a norma aplicável aos credores trabalhistas, qual seja, a previsão da CLT, em cujo regramento não possui qualquer limitação de valores, ou no diploma da LRF, que altera a qualidade do crédito. Na solução do conflito há que se considerar as previsões constitucionais dos arts. $1^{\circ}$ e $3^{\circ}$ da CRFB/88:

\footnotetext{
Art. $1^{\circ}$ A República Federativa do Brasil, formada pela união indissolúvel dos Estados e Municípios e do Distrito Federal, constitui-se em Estado Democrático de Direito e tem como fundamentos:

I - a soberania;

II - a cidadania;

III - a dignidade da pessoa humana;

$I V$ - os valores sociais do trabalho e da livre iniciativa;

$V$ - o pluralismo político.

Parágrafo único. Todo o poder emana do povo, que o exerce por meio de representantes eleitos ou diretamente, nos termos desta Constituição.

Art. $3^{\circ}$ Constituem objetivos fundamentais da República Federativa do Brasil:

I - construir uma sociedade livre, justa e solidária;

II - garantir o desenvolvimento nacional;

III - erradicar a pobreza e a marginalização e reduzir as desigualdades sociais e regionais;

IV - promover o bem de todos, sem preconceitos de origem, raça, sexo, cor, idade e quaisquer outras formas de discriminação.
}

Admitindo-se como vetor orientador de nossa prática o compromisso com o projeto civilizatório (referido alhures) sabemos que num sistema pluralista, as normas constitucionais sobre direitos sociais devem possuir abertura aportando diversas concretizações. Em última análise a interpretação constitucional é fundamentalmente concretizadora, tendo a tarefa de definir a proteção dos direitos fundamentais nela previstos. A rigor, não se trata da criação de um direito novo, mas sim aplicação de um direito fundamental já consagrado na Constituição.

A despeito da invocação da doutrina clássica em relação à antinomia jurídica, as regras dos critérios cronológicos, hierárquico e de especialidade nem sempre fornecem o completo instrumental para dar solução ao caso 
concreto. Assim mediante a defrontação para a aplicação dos dispositivos citados (art. $1^{\circ}$ da CRFB/88, art. 449 da CLT e art. 83 da LRF) precisamos invocar a aplicação do princípio da proporcionalidade. Este princípio busca, sobretudo, coibir e neutralizar o abuso do Poder Público no exercício das funções que lhe são inerentes, mormente no desempenho da atividade legislativa e regulamentar.

Relatando, ainda sobre este ponto, o pensamento de MARCELO PAPALÉO DE SOUZA ${ }^{41}$ ao refletir sob o prisma do princípio da proporcionalidade chega a seguinte conclusão:

“Feitas todas as considerações, temos que a regra do art. 83, I da LRF representa uma restrição a um direito fundamental dos direitos dos trabalhadores (praticamente a todos os relacionados no art. $7^{\circ}$ e seus incisos da Constituição Federal, pois os restringe). Para a apreciação devemos atentar para três aspectos: a) se o meio utilizados para alcançar o resultado pretendido é adequado; b) se é necessário o sacrifício de um dos valores constitucionais protegidos em favor de outro, considerando que o objetivo pode vir a ser alcançado de forma menos gravosa; c) se é justo ou razoável que, sob as condições do fato concreto, um ou mais dos princípios em jogo tenha precedência sobre o outro.

O meio utilizado pelo legislador, para dispor sobre a ordem de classificação dos créditos nos concursos coletivos, é adequada. O sacrifício do valor constitucionalmente assegurado ao trabalhador (art. $7 \mathrm{da} \mathrm{CF}$ ), considerando o objetivo a ser alcançado, não é de forma menos gravosa e não é justa e nem razoável a restrição do direito do trabalhador, eminentemente alimentar, em relação aos demais créditos exigidos na falência. A restrição imposta pelo art. 83, I da LRF não atende os critérios da razoabilidade e da proporcionalidade (...) figurando excesso de poder e desrespeito à norma constitucional” (grifos nossos).

E o autor continua em seu fulminante de raciocínio:

\begin{abstract}
"Não pode ser aceita a restrição exclusiva do crédito trabalhista, pois, quanto aos demais não há qualquer menção de limitação, ficando tal prejuízo somente aos credores trabalhadores. (...) Justificar a restrição de direito fundamental, limitação ao direito dos trabalhadores sob o argumetno de conter possíveis fraudes foge a todos os limites da razoabilidade. O subprincípio do dever de proporcionalidade, o da necessidade, estabelece que a medida restritiva deve ser indispensável para a defesa de determinado direito fundamental e que não possa ser substituída por outra igualmente eficaz, porém menos gravosa. Se o legislador quisesse proteger os direitos dos trabalhadores, no rateio, era só impor a limitação de 150 (cento e cinquenta) salários mínimos aos administradores da devedora falida e não a todos os empregados. Portanto, tal
\end{abstract}

\footnotetext{
${ }^{41}$ SOUZA, Marcelo Papaléo de, A inconstitucionalidade da restrição dos créditos trabalhistas na nova lei de falência art. 83, I, da lei 11.101/05, Revista LTr, São Paulo, vol. 71, n02, p. 135-141, fevereiro de 2007.
} 
medida extrapola os limites da necessidade da restrição. (...) se a intenção do legislador ;é fazer justiça social, até porque para ser justiça tem que ser social, a melhor solução seria estabelecer um limite para o pagamento preferencial dos preditos altos funcionários e não estabelecer limite para os trabalhadores de baixa renda" (grifos nossos).

Destarte, diante de todo o exposto, aderimos ao posicionamento esposado pela corrente majoritária da seara trabalhista, e até mesmo de alguns autores expoentes da área empresarial (tais como Penalva Santos e Sérgio Campinho), qual seja, pela inconstitucionalidade do inciso I do art. 83 da LRF (o qual confere limitação dos créditos trabalhistas à cento e cinqüenta salários mínimos). Tal orientação é fundamentada, sobretudo levando-se em consideração que não há qualquer limitação quanto aos créditos de outra natureza, configurando, portanto, esta restrição exclusiva, profundamente iníqua e prejudicial aos credores trabalhistas. 


\section{CONSIDERAÇÕES FINAIS}

O presente estudo teve por objetivo, como referido alhures, analisar os reflexos da LRF no Direito e no Processo do Trabalho tendo como pano de fundo o emblemático estudo prático do caso Varig. Com efeito, a análise das consequiências da nova lei (LRF) em relação ao Direito e Processo do Trabalho revela-se tarefa indispensável, mormente quando conduzida na tentativa de compatibilização dos institutos diversos, do Direito do Trabalho (predominantemente preocupado com os trabalhadores); do Direito Empresarial (essencialmente concernente aos credores e manutenção da empresa economicamente viável).

A complexidade acadêmica do "Caso Varig” é ao mesmo tempo sua maior virtude e também a maior dificuldade. Virtude na medida em que promove a interdisciplinaridade do Direito, posto que é considerado o leading case do tema. Em contrapartida, as dificuldades em lidar com o caso também são consideráveis. Grosso modo, pontuamos: a novidade da legislação e conseqüentemente a falta de orientação jurisprudencial e doutrinária firme acerca do tema, inúmeras imprecisões e equívocos nas notícias referentes ao caso nos meios de comunicação, a importância econômica e estratégica da Varig para o mercado de aviação brasileiro, o número de pessoas envolvidas diretamente no processo, dificuldades práticas cartoriais inerentes ao andamento processual tais como o volume de documentos administrados, volume de publicações, número de partes, necessidade de assegurar ampla divulgação de informações seguras, entre outras.

No âmbito da disputa de competência entre a vara empresarial e a trabalhista, acreditamos ser esta pertencente à esfera laboral, tendo em vista que a competência jurisdicional não deve ser confundida com os efeitos decorrentes da recuperação judicial. 
Não se trata, contudo, de desqualificar os argumentos da orientação empresarial. Ao contrário, cumpre considerar-se o elevado grau do debate no plano técnico pelos bons argumentos trazidos à baila pela doutrina empresarial, sobretudo os de ordem prática como a necessidade de fechamento dos fatores de composição do preço antes do leilão judicial.

A despeito deste raciocínio, resumidamente, em verdade, a LRF cuida somente da mudança de ênfase na sucessão em caso de recuperação judicial, sem jamais ser capaz de per si, de afastar a competência constitucional da Justiça Laboral.

Finalmente, como retro mencionado, o STJ decidiu ser competente para apreciar a matéria da sucessão trabalhista a vara empresarial e atualmente a questão encontra-se sob judice, aguardando julgamento do recurso extraordinário no STF, que decidirá derradeiramente, pacificando o debate.

Movendo-se para a discussão acerca da polêmica do art. 60 § único da LRF, qual seja, sobre a aplicação da sucessão trabalhista em caso de alienação da unidade produtiva de empresa em recuperação judicial, o método de trabalho busca fazer um contraponto ao discurso dominante (exclusão da sucessão trabalhista), meramente para fins de problematizar a questão. Para a compreensão crítica da corrente dominante, recorreu-se ao desdobramento analítico do tema em três níveis: argumentos jurídicos, econômicos e ideológicos.

Consoante aos principais argumentos jurídicos apresentados, quais sejam a preservação da empresa (art. 47 da LRF) e a ratio legis, resta patentemente claro que não há possibilidade de uma interpretação extensiva do aludido dispositivo (art. 60 § único da LRF) por não ser concebível em hermenêutica atribuir a interpretação extensiva de uma norma jurídica restritiva de direitos. 
Ademais, especificamente sobre a ratio legis, diante da análise adequada do processo legislativo originário da LRF, não resta outra conclusão senão a aceitação da aplicação da sucessão trabalhista, visto que houve proposta de exclusão expressa da sucessão na recuperação judicial tendo sido a mesma rejeitada.

No âmbito da argumentação de ordem econômica, surgem as maiores dificuldades, visto que posições antagônicas (investidores versus trabalhadores) provocam o acirramento no conflito de interesse classista. Muito plausível e respeitável a linha argumentativa baseada no estímulo para sensibilizar o investidor e garantir o crédito, necessário ao soerguimento da atividade empresária.

Sem dúvida que é necessário que exista na legislação mecanismos de salvaguardas visando à recuperação dos devedores que eventualmente estejam em situação econômica debilitada, afastando as conseqüências prejudiciais a toda sociedade pela cessação das atividades.

Todavia, como analisado anteriormente, todos devem suportar sacrifícios e fazer concessões em razão da crise da empresa, e não tão somente os credores trabalhistas. O inadmissível é interpretar um dispositivo genérico contra a previsão legal expressa, para desvalorizar o trabalho.

De outro giro, na esteira do conflito classista, surge o debate acerca dos argumentos ideológicos sobre o caso. Em verdade, a polêmica ideológica é um mero desdobramento da argumentação jurídica e econômica. Fato é que a rigor, a interpretação economicista do Direito termina por visar somente à manutenção da empresa, seja a que custo for para os credores e trabalhadores. Neste sentido, ainda no âmbito dos argumentos ideológicos, urge destacar a necessidade imprescindível de um compromisso com o projeto civilizatório das relações trabalhistas.

Por outra banda, restou esgotada a discussão em torno da inconstitucionalidade do inciso I, do art. 83 da LRF, sobre a limitação dos créditos trabalhistas. Ao fim e ao cabo, após demorada análise dos 
dispositivos que disciplinam pagamento antecipado ao dos credores elencados no art. 83, percebe-se que a ênfase do novo diploma privilegia o capital em detrimento do trabalho em razão da crise da empresa. Evidenciada a inconstitucionalidade do referido dispositivo tendo em vista que não pode ser aceita a restrição exclusiva do crédito trabalhista, pois, quanto aos demais não há qualquer limitação.

Por fim, registre-se apenas que o presente estudo não possui a pretensão de esgotar o tema em debate. Justo o oposto, sujeita-se a uma série de incompletudes, lacunas e imperfeições. A principal dificuldade desta tarefa é que o cenário jurisprudencial e doutrinário começa a ser construído gradualmente, a partir de uma legislação nova e complexa, que integra diversas áreas Direito. Não podemos olvidar que na medida em que o julgamento do STF decida a questão, a discussão sobre o tema perde, ao menos parcialmente, objeto e significação no plano prático. Todavia, no âmbito acadêmico, sua importância permanece e certamente o debate lança luzes sobre novas possibilidades de conflitos análogos. Válido, portanto, o esforço para dar conta do estado da arte dos argumentos das principais teses em debate neste conflito. 


\section{REFERÊNCIAS BIBLIOGRÁFICAS:}

ALMEIDA, Amador Paes de; ALMEIDA, André Luiz Paes de. A sucessão trabalhista na recuperação judicial, Revista LTr, São Paulo, vol. 71, nº4, p.442-445, abril de 2007.

ANDRADE, Carlos R. Fonseca. "O Direito do Trabalho e a Lei de Recuperação de Empresas” In: SANTOS, Paulo Penalva (org.) “A nova Lei de Falência e de recuperação de empresas”, RJ, Ed. Forense, 2006. p. 75107.

AYOUB, Luiz Roberto. Recuperação de empresas: Uma lei de estímulos e atrativos - reflexões gerais, Revista da Escola Nacional da Magistratura Associação dos Magistrados Brasileiros, Ano III, n05, p. 90-103, maio de 2008.

CÂMARA, Alexandre Freitas, Lições de Direito Processual Civil, Volume I, 16ª edição, RJ Ed. Lumen Juris, 2007

CAMPINHO, Sérgio; Falência e recuperação de empresa: o novo regime da insolvência empresarial, 9a edição, RJ, Ed. Renovar, 2008

COELHO, Fábio Ulhoa, Comentários à nova lei de falência e recuperação de empresas, 5 edição, RJ, Ed. Saraiva, 2008.

DELGADO, Maurício Godinho, Curso de Direito do Trabalho, Ed: Ltr, $5^{\circ}$ edição, SP, 2006.

GOMES, Orlando; GOTTSCHALK, Elson. Curso de Direito do Trabalho, 18. Edição, RJ, Ed. Forense.

GONTIJO, Vinícius José Marques. Efeitos da falência do empregador na ação de execução de créditos trabalhista, Revista LTr, São Paulo, vol. 71, n¹2, p.1488-1499, dezembro de 2007. 
Jornal Último Segundo. Disponível em <http://ultimosegundo.ig.com.br/ economia/2007/03/28/> Acesso em 14 jun, 2008.

LIEBMAN Apud GRINOVER, Ada Pellegrini, Teoria Geral do Processo, 22ª edição, SP, Ed. Malheiros, 2006.

MAUAD, Marcelo. Os direitos dos trabalhadores na lei de recuperação e de falência de empresas, $1^{\text {a }}$ edição, SP, Ed. LTr, 2007.

MAUAD, Marcelo. Bases Constitucionais da lei de recuperação e falência: função social da empresa e os direitos dos trabalhadores. Disponível em $<$ http://www.unisolbrasil.org.br>. Acesso em 01 set. 2008.

MONTEIRO, Cristiano Fonseca. Viação Aérea Rio-Grandense: Quem está acima de tudo?. In: KIRSCHNER, Ana Maria (Org.). Brasil: Mosaico dos anos 90, RJ: IFCS/UFRJ, p. 73-101, 1999.

MONTEIRO, Cristiano Fonseca. A Varig e o Brasil entre o desenvolvimento nacional e a competitividade global. Civitas- Revista de Ciências Sociais do Departamento da PUC-RS. Rio Grande do Sul, v. 7, n.1, p. 35-58, jan/jun. 2007.

MONTEIRO, Cristiano Fonseca,. A trajetória da Varig do NacionalDesenvolvimentismo ao consenso Neoliberal. Rio de Janeiro. 2000. 120p. Dissertação (Mestrado em Sociologia) Departamento de Sociologia e Antropologia da Universidade Federal do Rio de Janeiro

MONTEIRO, Cristiano Fonseca. A dinâmica política das reformas para o mercado na aviação comercial brasileira (1990-2002). Rio de Janeiro, Agosto 2004. 252 p. Tese (Doutorado em Sociologia e Antropologia) IFCS/UFRJ.

MORAES, Evaristo de, Sucessão nas obrigações e a Teoria da empresa, $1^{\mathrm{a}}$ edição, RJ, Ed. Forense, 1960. 
MOURA, Marcelo Antônio de O. A.; GÓIS, Luiz Marcelo Figueiras. Os efeitos da falência nas relações materiais e processuais de trabalho, Revista LTr, São Paulo, vol. 70, nº11, p.318-332, novembro de 2006.

OLIVEIRA, Celso Marcelo de, Comentários à nova lei de falência e recuperação de empresas, $1^{\mathrm{a}}$ Edição, SP, Ed. IOB Thomson, 2005.

SANTOS, Joaquim de V. Penalva, Recuperação judicial de empresas, $1^{\mathrm{a}}$ edição, RJ, Ed. Espaço Jurídico, 2007.

SOUZA, Marcelo Papaléo de; A nova lei de recuperação e falência e as suas conseqüências no Direito e no Processo do Trabalho, $2^{\mathrm{a}}$ edição, SP. Ed. Ltr, 2006.

SOUZA, Marcelo Papaléo de, A inconstitucionalidade da restrição dos créditos trabalhistas na nova lei de falência art. 83, I, da lei 11.101/05, Revista LTr, São Paulo, vol. 71, nº2, p. 135-141, fevereiro de 2007.

SPONVILLE, André Comte. Pequeno tratado das grandes virtudes, $12^{\mathrm{a}}$ edição, SP, Ed. Martins Fontes, 2007.

$33^{\circ}$ VT/R, RT 1053-2006-033-01-00-7, sentença, Juiz Titular Múcio Nascimento Borges, 30 ago, 2006.

01 VE/RJ - 2005.001.072887-7, decisão, Juiz: Luiz Roberto Ayoub, Rio de Janeiro, 05 jun, 2006.

$19^{\mathrm{a}}$ VT/RJ, RT 1725-2006-019-01-00-8, sentença, Juíza Substituta: Fernanda Stipp, Rio de Janeiro, 06 out, 2007.

Ação Civil Pública (em dependência com as ACPS no. 1053-2006-033-0100-7 e 1065-2006-033-01-00-1) subscrita pelos Procuradores do Trabalho da $1^{\text {a }}$ Região: Rodrigo de Lacerda Carelli e João Hilário Valentim. 


\section{ANEXOS:}

Anexo I - Entrevista concedida em 22/10/2008 - Juiz Titular da $1^{\text {a }}$ Vara Empresarial Dr. Luiz Roberto Ayoub

1 - Poderia a empresa "em recuperação" ser comprada por outra do mesmo grupo?

Em verdade isso não ocorreu no caso da Varig, pois a Varig Log já não pertencia ao mesmo grupo. A Varig Log pertenceu à Varig, mas foi alienada a um terceiro (Aero LB) e depois a Varig Log comprou a Varig. No passado ela foi uma subsidiária, mas não na época da compra, já não pertencia.

2 - A Varig foi vendida em leilão a Varig Log por um preço muito menor do que o que mais tarde foi vendida a Gol segundo informações dos jornais. Corrija os valores se estiverem errados por favor, mas foi algo nesta ordem: Varig vendida para a Varig Log em leilão por U\$ 24 milhões de dólares e menos de 1 ano (09 de abril de 2007) foi vendida para a Gol por U\$ 320 milhões de dólares. Essas diferenças de valores afeta o processo de algum modo?

Os números divulgados na imprensa são falsos. O valor de 24 milhões é falso. No dia do leilão a Varig só tinha 2 aviões. O preço é uma composição de fatores. É um ajuste complexo. O valor de 24 milhões não incluía uma série de valores tais como as debêntures no total de 100 milhões, mas a assunção de contratos de transporte a executar mais a assunção do programa Smile. Salvo engano ela foi adquirida por algo em torno de 277 milhões de dólares. O valor de 24 milhões é um equívoco que a mídia coloca e se esquece que o resto também é preço. E havia um risco de sucessão enorme naquele momento, o risco é um fator de preço. Aproximadamente uns 9, 10 meses depois quando a GLAI (Gol Linas Aéreas Inteligentes), que é quem controla a Gol adquiriu essa UPV (unidade produtiva de valor), pagou 
muito mais, porque já eram 19 aviões, com recursos já investidos, já tinha uma musculatura maior, e também já não havia tanto risco de sucessão porque o STJ já havia definido que a competência era minha (vara empresarial). Então são esses fatores que não saem na imprensa. O que sai é: “Venderam por 24 milhões que absurdo...mas não é nada disso”. A imprensa coloca o que ela quer pois é ignorante no setor jurídico. Ela não sabe o que aconteceu, não sabe o que é risco de sucessão e que isso entra no preço. A situação fática no momento da venda era completamente outra. Então ela não foi comprada por 24 milhões e não foi vendida por 300 milhões. Ela foi vendida por 277 milhões e depois foi vendida para a GLAI por mais de 500 milhões.

3 - Sobre a disputa de competência entre a vara empresarial e a trabalhista. Quais seriam os principais argumentos para afastar a competência da Justiça Trabalhista?

O STJ entendeu que é a vara empresarial a competente. A matéria foi levada a recurso extraordinário para o Supremo. Não tem a decisão final, mas já tem a manifestação do PGR. O STJ julgou por 11 a 0 que a competência é da empresarial. Do conflito houve o recurso extraordinário, o relator é o ministro Ricardo Lewandowski, e no momento já contamos com esse parecer favorável do Sub Procurador Geral. Quem é que preside o leilão é o juiz que está com a recuperação, ele é que tem que dizer se há ou não sucessão porque isso é componente do preço. Você vai levar uma coisa sem saber se há ou não sucessão, qual é o preço? Até porque se eu vou participar de um leilão e não há definição se há ou não sucessão eu não participaria, porque eu não sei qual é o preço. Veja a insegurança jurídica. Então a manifestação tem que ser prévia. Por isso que eu sempre defendi que a competência é da vara empresarial e não da justiça do trabalho. E foi assim é que o STJ julgou. Não julgo a questão trabalhista, a única competência nossa, é a de dizer se há sucessão trabalhista ou não. A lide trabalhista quem resolve é a justiça do trabalho. Agora como é que eu vou 
deixar de me pronunciar sobre a existência ou não de sucessão e colocar um ativo para venda em leilão judicial? Eu não posso, isso é inviável no plano prático. Em Brasília no TST quando eu e o Prof. Paulo Penalva fomos fazer uma palestra eu fiz até um ensaio. Chamei uma palestra de cem magistrados do trabalho e perguntei: Quem acha a competência é da Justiça Trabalhista? Daí a maioria levantou a mão. Perguntei: Quem acha que não tem? Uma minoria. Então falei: Amanhã eu vou alienar um ativo, daí um de vocês (que acreditam ter a competência) vai dizer que tem sucessão, outros poderão dizer que não tem, olha só a instabilidade e insegurança. Isso tem que se concentrar em uma única pessoa que é quem preside o leilão. Se você for pegar a doutrina empresarial sobre a recuperação de empresa, ela é unânime em dizer que não há sucessão e que a competência é da justiça empresarial. Inclusive no TST a manifestação deles naquele momento é a de que não há sucessão, a única divergência é que eles entendem que a competência é deles. Mas eu não compreendo como. Em que momento eles dirão isso? Depois do leilão? Isso seria loucura, incoerente... Você participaria de um leilão se não soubesse se há ou não sucessão? Ninguém participaria. Se participasse pagaria um preço pequeno devido ao risco de no futuro alguém dizer que há sucessão.

4 - Questão sobre a polêmica sobre a interpretação do art. 60 § único LRF: Questão da sucessão em caso de alienação da unidade produtiva em recuperação judicial. Qual é a diferença do controle exercido pelo juiz sobre o dinheiro na recuperação e na falência?

$\mathrm{O}$ art. 83 fala da ordem do recebimento dos créditos. (A empresa não foi vendida, foi vendida a UPV, a empresa continua e hoje ela se chama Flex, porque a marca Varig também foi vendida). O dinheiro foi arrecadado para injetar na recuperação. Pode ser dissipado? Pode se ela mal gerir. A diferença é que na falência você realiza os ativos para pagar os credores, na recuperação você pega o dinheiro e injeta na empresa para tentar se reerguer. O que sempre ocorreu de preocupação foi o seguinte: E se a 
empresa não se reerguer? Perdeu-se aquilo tudo? Sim, há uma chance. Havia por exemplo, 20 milhões na empresa, será que era melhor pegar esse dinheiro e pagar $0,2 \%$ dos credores, ou reinjetar esse dinheiro na empresa para tentar reerguer e pagar os credores também? Se houvesse a falência, os trabalhadores não receberiam. Só para você entender com precisão: Se houvesse a falência da Varig, qual o valor que a empresa teria para pagar aos diversos credores? Primeiro recebe o credor trabalhista, mas não 150 salários mínimos, mas sim limitados a 5 salários mínimos, depois vem o credor extraconcursal. Primeiro é o art. 54, depois é o inciso I do 84, depois é que vem o inciso I do 83. Certa vez fui questionado por um juiz trabalhista que alegava que primeiro teria que se pagar os 150 salários mínimos, mas isso é um engano. A única preferência trabalhista é de créditos limitados até 5 salários mínimos. Depois o extraconcursal consome todos os ativos. Então ele teria os 150 salários mínimos prejudicados. Se houvesse a falência da Varig, qual seria o ativo que teria para ser liquidado para pagar os credores? Nenhum. Mas na recuperação como é que teve? $\mathrm{Na}$ falência o art. 195 disciplina que a Varig teria perdido a concessão, eu até estou escrevendo um artigo criticando este dispositivo da LRF, ela perderia os consectários, que são os slots que são horários e local de pouso e decolagem. Isso só foi mantido porque a empresa não faliu. Existiam na recuperação, ativos que poderiam ser alienados, se houvesse a falência, perderia a concessão, perderia tudo. Não teria nenhum avião, é tudo leasing. Teriam alguns prédios, alguns imóveis, que eram valores pequenos. $\mathrm{O}$ administrador judicial à época apresentou um relatório. A Varig, se quebrasse, teria em termos de ativos naquela ocasião aproximadamente 80 milhões de reais, que se levado à hasta pública, cairia para 40, 50 milhões, para enfrentar um endividamento de 7 bilhões. Sendo que o extraconcursal girava em torno de 1 bilhão, ou seja, o trabalhador iria receber 5 salários mínimos, depois, iria tudo para o extra, aliás não pagaria completamente nem o credor extraconcursal. Infelizmente, a história de receber 150 salários mínimos é balela, é totalmente desconhecer a lei. Os 5 salários 
mínimos já foram pagos e graças à recuperação judicial. Já paguei aproximadamente 20\% dos créditos trabalhistas. Em relação a quase 3 mil trabalhadores, eu liquidei, paguei tudo. Eles tinham menos que 11 mil para receber. Eu paguei com as debêntures.

5 - Pergunta advém de notícias amplamente divulgadas na mídia (jornal O Globo em 14 de maio de 2008) sobre fiscais nomeados administradores da Varig em recuperação que supostamente, segundo a reportagem, estariam recebendo remuneração de 200 mil por mês. Há critérios para ser administrador judicial da empresa em recuperação?

Isso é mentira, esta notícia é um absurdo. A lei exige a figura do administrador judicial. E a lei fala em uma remuneração de até $5 \%$, eu nomeei uma empresa multinacional chamada Deloitte. A complexidade é enorme, foram mais de 1000 (mil) pessoas envolvidas. A lei fala em até $5 \%$, nós arbitramos em cerca de 0,2\% para uma empresa que colocou centenas de pessoas trabalhando. Toda a nomeação e contratação da empresa foi justamente para não ter que contratar mais ninguém. Todo o corpo da Deloitte ficou a nossa disposição. Tinham engenheiros, economistas, contadores, advogados.

6 - Pergunta também derivada de notícias: sobre a disputa societária da Varig Log, existem 3 sócios (Antônio Audi, Luiz Gallo e Marcos Haftel) da VOLO (comprou a Varig Log) seriam laranjas do chinês representante do fundo de investimento norte americano Matlin Patterson. Pela nossa legislação o controle acionário não pode ser exercido por estrangeiro. Há algo nesta disputa acionária que influencie o processo de recuperação?

Na verdade isso não tem relação nenhuma com a recuperação judicial. A Varig Log é outra coisa. Quem atestou a regularidade da composição acionária da Varig Log foi a ANAC, que é a competente para isso, houve também manifestação da Receita Federal e do Banco Central. A ANAC que atesta a validade da composição acionária porque o código de aviação 
aeronáutico brasileiro atesta que não pode haver controle superior a $20 \%$. À época participaram do leilão empresas que tinham a composição acionária atestada pela ANAC e foi a VarigLog quem arrematou, mas é uma discussão que não tem relação com a recuperação.

7 - Como foi o processo no todo, basicamente suas impressões gerais?

As dificuldades principais foram: primeiro o fato de que era uma lei nova, muito complexa, uma lei que demanda uma formação multidisciplinar por parte de um juiz. Não é possível conhecer toda a complexidade deste processo sem ter uma noção mínima de economia, de administração. Uma visão prospectiva, qual é a conseqüência da decisão. Se a Varig falisse, seria bom para o país? Seria bom para os trabalhadores? Numa visão macro, seria bom para a nação, numa visão micro, mas não menos importante, seria bom para os trabalhadores? Então toda essa formação multidisciplinar é que foi a grande dificuldade porque nós não tínhamos a cultura da recuperação. Tínhamos a cultura da lei antiga, pró credor. Se quebrar paga-se os credores e na realidade, muitas vezes não se chegava a conseguir pagar. Hoje a lei busca um equilíbrio entre credor e devedor. É uma lei que estabelece o cenário do debate. Quem decide não é o juiz, quem decide são os credores e devedores. É uma lei de amplo debate, são eles que chegaram a conclusão de que deveria haver a recuperação da empresa e não a falência, porque as três classes aprovaram e foi quase unânime a decisão. Mas evidentemente, como você acaba contrariando interesses aqueles que defendiam a recuperação em um determinado momento começam a querer a falência. Há muita agenda paralela e interesses cruzados que eu não posso considerar como interesses legítimos, idôneos ou éticos. Você tem de tudo, só que no Judiciário, essas pessoas não conseguiram espaço. 
Anexo II - Entrevista concedida em 29/10/2008 - Ex-comissária de bordo da Varig - Sra. Marta Rezende Osório

1 - Quanto tempo você trabalhou para a Varig, e como foi sua percepção da crise? Quando efetivamente os funcionários tomaram conhecimento da situação?

Foram 26 anos de trabalhos de trabalhos prestados. Haviam alguns rumores mas ninguém acreditava que fosse realmente quebrar. A percepção da crise só veio quando começaram a cancelar vôos, atrasar salários (em 26 anos de trabalho eles nunca tinham atrasado um mês sequer), e começaram a não pagar os demais credores, terceiros. Minha ficha realmente só caiu quando durante a Copa do Mundo, que foi na Alemanha e eu havia sido escalada para trabalhar, tinha programação de muitos vôos para este destino, e de repente vimos o cancelamento da maioria deles. Daí percebi que a crise era realmente grave.

2 - Houve algum esclarecimento por parte da Direção da empresa sobre a situação?

Não. A Direção nunca se manifestou. Muitos só perceberam a situação quando foram chegando as cartas de demissão. Não houve um real esclarecimento como ainda hoje não há. Estamos como cegos em meio a um tiroteio.

3-O critério de demissão especificado no Acordo Coletivo foi respeitado? Creio que não. Primeiro eles demitiram os que já estavam aposentados e permaneciam trabalhando. Em seguida os que estavam a beira de se aposentar. Depois não houve mais qualquer outro critério. Claro que como em todo lugar houve um pequeno e seleto grupo de funcionários que foram avisados da situação da empresa antes da quebra e que se demitiram antes de tudo ocorrer, conseguindo assegurar seus créditos. 
4 - Houve algum tipo de programa de demissão voluntária? Em caso afirmativo houve algum tipo de pressão da empresa para a adesão? Sim, houve o programa. Houve certa pressão para quem já estava aposentado ou bem próximo disto, aderissem ao programa de demissão voluntária.

5 - Comente brevemente a situação do Aerus. Funcionários tinham acesso a informações sobre as aplicações do fundo? Sabiam de sua situação de crise?

O Aerus era o fundo de pensão criado pela Fundação Rubem Berta (FRB), e tinha aproximadamente 22 anos. Os empregados contribuíam com 10 a no máximo 13 \% de seus rendimentos. Havia rumores de má gestão sim, que o dinheiro era mal aplicado. O fato era que os funcionários não tinham nenhum acesso as contas do Aerus. Eu mesma, que contribuí todos estes anos, tenho cerca de R 198 mil reais a receber e até hoje, não recebi nada.

Anexo III - Entrevista concedida em 29/10/2008 - Presidente da ACVAR Associação dos Comissários da Varig - Sr. Reynaldo Filho

1 - Houve respeito aos critérios de demissão previamente pactuados no Acordo Coletivo?

O plano de recuperação para ser aprovado tinha que ter Acordo Coletivo. Eles não respeitaram nem o Acordo Coletivo, nem a Lei. No meu caso, sou líder sindical, possuo estabilidade pela lei, mesmo assim, fui um dos primeiros a ser demitido. Existem pessoas com ordem judicial de reintegração, e que não conseguem ter a decisão cumprida porque eles entram com uma série de recursos, protelando o cumprimento. 
2 - Há previsão legal de que deve haver aprovação dos credores quanto ao plano de recuperação. Como foi esta negociação, e a questão da representatividade?

A negociação foi ruim. Só foi aceita a representação da categoria, pelos pelegos do Sindicato dos Aeronautas. Tentamos articular um grupo próprio de representação no qual fizemos uma assembléia em 2005, na qual compareceu o expressivo número de mais de 600 aeronautas (isso representa quase a totalidade dos funcionários que não estavam trabalhando em trânsito) e votamos uma comissão para se fazer representar perante o processo de recuperação. Escolhemos esta comissão justamente para excluir os pelegos e representar nossa categoria. Porém o juiz da vara empresarial desconsiderou essa comissão especial e inviabilizou nosso trabalho neste sentido. Nas assembléias dos credores, faziam de tudo para que nossa comissão não se manifestasse, inclusive com a conivência da Deloitte (administradores judiciais). Criaram uma assembléia fantasma e esse plano de recuperação deu um grande calote nos trabalhadores. Pelas contas que eles fazem eu tenho cerca de R\$ 20 mil reais a receber de FGTS. Na verdade tenho só de FGTS que eles não depositaram mais de R\$ 300 mil reais. Em média, o valor das ações trabalhistas de um comissário da Varig gira em torno de 300 mil reais e de um comandante, algo em torno de 600 mil reais. Isso sem incluir dano moral.

3 - Como foi a percepção da crise da empresa perante os funcionários? As pessoas não queriam acreditar nas evidências. Em 2000 a Associação dos Pilotos percebendo a ponta do iceberg contratou uma empresa para fazer uma espécie de auditoria. Contrataram excelentes profissionais da área, tais como, Paulo Rabelo de Castro, Jorge Lobo, entre outros. Essas consultorias foram pagas pelos trabalhadores. Com este trabalho ficou diagnosticado que a situação era severamente crítica. Porém houve muito problema com a contra-informação e contra-propaganda que vinha por parte da direção do Sindicato da categoria. 
4 - Houve algum programa de demissão voluntária?

Sim. A empresa no último momento resolveu fazer um programa de demissão voluntário, e foi pior agravando a situação, porque saiu distribuindo nota promissória mesmo sabendo que não conseguiria pagar.

5 - Comente um pouco sobre o Aerus.

Os problemas do Aerus foram realmente detectados em 2002 e tentaram passá-los na venda da Varig. Mesmo o Aerus chegando a um ponto de insolvência tão grande, eu continuei pagando até o último mês, acreditando que de alguma forma eu estava ajudando a salvar a empresa. Não podemos esquecer também que a União Federal também tinha o dever de fiscalizar o Aerus. E hoje, como o fundo está liquidado, não adianta cobrar porque está tudo bloqueado. 